\title{
ESPÉCIES TROPICAIS PARA MANUFATURA DE PAINÉIS COMPENSADOS
}

FRANCISCO MOTA DA SILVA

Eng. Operacional de Indústria da Madeira

Orientador: Prof. Dr. Ivaldo Pontes Jankowsky

Dissertação apresentada à Escola Superior de Agricultura "Luiz de Queiroz", da Universidade de São Paulo, para obtenção do título de mestre em Ciências, Área da Concentração: Ciências Florestais

\author{
Piracicaba \\ Estado de São Paulo - Brasil \\ Agosto / 1994
}


Ficha catalografica preparada pela Seço de Livros da. Divisáo de Eiblicteca e Documentaçă - FCLQ/USF

\footnotetext{
Silva, Francisco Mota

S586e Especies tropicais para manufatura de paineis compensados. Firacicaba, 1994. $68 \mathrm{~B}$.

Diss. (Mestre) - ESALQ

Eibliogratia.

1. Compensado de madeira - Amazonia $Z$. Laminado de madeira - Amazonia 3. Produto florestal Uso - Amazonia I. Escola Superior de Agricultura Luiz de Gueiraz, Firacicaba.
}

CDD $\quad 674.834$

674.935 


\section{ESPÉCIES TROPICAIS PARA MANUFATURA \\ DE PAINÉIS COMPENSADOS}

\section{FRANCISCO MOTA DA SILVA}

Aprovado em: 25.10.94

Comissão julgadora:

Prof. Dr. Ivaldo Pontes Jankowsky

ESALQ/USP

Prof. Dr. José Nivaldo Garcia ESALQ/USP

Prof. Dr. Hernando Afonso Lara Palma

UNESP

Prof. Dr. Ivaldo Pontes Jankowsky

Orientador 
À minha esposa VILMA, pelo companherismo, amizade, compreensão e apoio neste momento da minha carreira profissional, aos meus filhos MARIANE e HENRIQUE, com desejo de que vivam num mundo sempre melhor,

e aos meus pais MANOEL e DOMINGAS (in memorian), por tudo o que me proporcionaram em vida e a quem eu devo a minha formação 


\section{AGRADECIMENTOS}

- Ao Prof. Dr. IVALDO PONTES JANKOWSKY, pela orientação, amizade e incentivo durante a realização deste curso.

- Ao Prof. Dr. José Nivaldo Garcia, pela amizade, sugestões e incentivo durante a realização deste trabalho.

- Ao Instituto Nacional de Pesquisas da Amazônica - INPA, pela oportunidade que me proporcionou para que pudesse realizar este curso de Mestrado.

- Ao Prof. Msc. Márcio Roberto Gaioto pela amizade e colaboração durante o transcorrer deste curso.

- Aos funcionários do Departamento de Ciências Florestais da ESALQ/USP, especialmente a Luis Eduardo Facco pela amizade e pelo trabalho de digitação e composição gráfica desta dissertação.

- Aos funcionários do setor de Laminados e Compensados do INPA, especialmente aos senhores Hamiltom Pinheiro de Matos, Rivanilson Galvão da Costa, Nizevalter Azevedo da Silva e Tertuliano W. Cabral, pela valiosa colaboração na obtenção dos dados com os quais foi possível a elaboração deste trabalho.

- A Sra. Tereza Vieira da Encarnação pelos seus prestimosos serviços de procuradora, durante a maior parte de minha estada em Piracicaba.

- Aos Senhores Roosevelt Rêgo Lopes e Jorge Luis de O. Jacinto pelos serviços de desenhos da dissertação.

- Ao Instituto de Pesquisa Tecnologica do Estado de São Paulo - IPT, na pessoa do Dr. João Peres Chimelo, pelo auxílio nos ensaios mecânicos.

- Aos professores do curso de Pós-Graduação em Ciências Florestais pela amizade e o conhecimentos absorvidos. 
- Ao setor de anatomia da madeira do INPA, pela identificação das espécies de madeiras aqui estudadas.

- A todos aqueles que direta ou indiretamente colaboraram, para que este curso fosse realizado. 


\section{SUMÁRIO}

LISTA DE FIGURAS ...................................................... viii

LISTA DE TABELAS ....................................................... $\mathbf{x}$

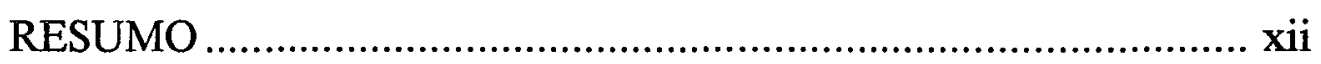

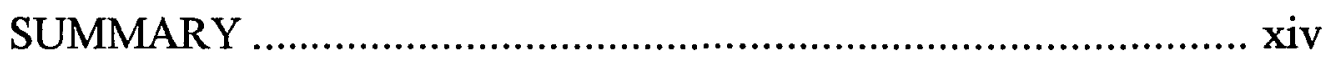

1. INTRODUÇÃO ........................................................... 01

2. REVISÃO DE LITERATURA......................................... 03

2.1. A produção de painéis compensados............................... 03

2.2. Relação entre a matéria-prima, o processo e o produto ........ 13

2.3. A utilização de espécies tropicais na manufatura de compensa-

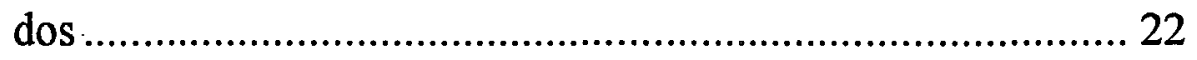

3. MATERIAIS E MÉTODOS............................................. 27

3.1. Espécies utilizadas............................................... 27

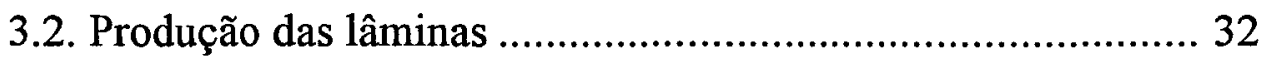

3.3. Avaliação da qualidade das lâminas.............................. 34

3.4. Manufatura e qualificação do compensado ........................ 37

4. RESULTADOS E DISCUSSÃO ........................................ 41

4.1. Laminação e secagem ............................................... 41

4.2. Qualidade das lâminas .............................................. 45

4.3. Avaliação do compensado ............................................. 55

4.4. Recomendações de uso ............................................. 58 
4.5. Recomendações de pesquisas.

5. CONCLUSÕES 61

6. REFERÊNCIAS BIBLIOGRÁFICAS 63 


\section{LISTAS DE FIGURAS}

Figura 1. Composição do compensado mostrando a alternância da direção das fibras e a posição de capa, miolo e intermediária

Figura 2. Relações geométricas entre a tora, a faca e a barra de compressão

Figura 3. Representação esquemática macroscópica de uma seção do tronco.

Figura 4. Representação esquemática dos corpos de provas para teste de tração normal (T) e do número e profundidade das fendas de laminação (F)

Figura 5. Número e profundidade das fendas de lâminação

Figura 6. Esquema de amostragem e execução do ensaio de cisalhamento na linha de cola.

Figura 7. Representação gráfica da correlação entre a rugosidade das lâminas e a densidade básica.

Figura 8. Representação gráfica da correlação entre a espessura real das lâminas e a densidade básica, para as espécies estudadas

Figura 9. Representação gráfica da variação na espessura das lâminas em função da densidade básica

Figura 10. Representação gráfica da correlação entre a tensão de ruptura das lâminas a tração normal e a densidade básica...

Figura 11. Representação gráfica da correlação entre a resistência corrigida e a densidade básica 
Figura 12. Representação gráfica da correlação entre a tensão de ruptura ao cisalhamento, na condição seca, e a densidade básica 


\section{LISTAS DE TABELAS}

Tabela 1. Características gerais das madeiras, com base em LOUREIRO et. al. (1979) .............................................. 29

Tabela 2. Características das toras ensaiadas .................................... 30

Tabela 3. Defeitos apresentados pelas toras ensaiadas, com base em GROSSER (1980).

Tabela 4. Condições de aquecimento das toras e temperatura no rolo resto

Tabela 5. Regulagens do torno e espessura nominal visada............... 33

Tabela 6. Formulação do adesivo utilizado ........................................ 38

Tabela 7. Condições de montagem e prensagem............................... 39

Tabela 8. Resumo do comportamento das espécies durante os processos de laminação e secagem..................................... 41

Tabela 9. Avaliação da rugosidade das lâminas ................................ 43

Tabela 10. Medidas dos teores de umidade inicial, final e retração tangencial das lâminas .................................................. 44

Tabela 11. Espessura média das lâminas secas ................................. 46

Tabela 12. Valores da tensão de ruptura das lâminas a tração normal ..

Tabela 13. Resultados da avaliação do número e profundidade das fendas de laminação ..................................................... $\quad 50$

Tabela 14. Valores de resistência corrigida para a tensão normal........ 51

Tabela 15. Defeitos: possíveis causas e medidas corretivas ................ 53

Tabela 16. Valores de resistência ao cisalhamento e falha na madeira das espécies estudadas nas condições seca e úmida. 
Tabela 17. Mínimo aceitável de falha na madeira em função da resistência ao cisalhamento, para linhas de cola à prova d'água (Norma NBS/PS 51-71)...................................... 56

Tabela 18. Desqualificação: possível causas e medidas corretivas....... 58 


\title{
ESPÉCIES TROPICAIS PARA MANUFATURA \\ DE PAINÉIS COMPENSADOS
}

\author{
Autor: Francisco Mota da Silva \\ Orientador: Prof. Dr. Ivaldo Pontes Jankowsky
}

\section{RESUMO}

Neste trabalho estudou-se a viabilidade técnica para a produção de lâminas e compensados, com madeiras tropicais, avaliando-se o comportamento das espécies Ucuúba branca (Osteophloeum platyspermum Warb.), Cedrorana (Cedrelinga catenaeformis Ducke), Louro gamela (Nectandra rubra (Maz.) C. K. Allen), Breu vermelho (Protium puncticulatum Macbr.), Cardeiro (Scleronema micranthum Ducke), Guariúba (Clarisia racemosa R. et. Pay.), Piquiarana (Cariocar pallidum Aubl.), Cupiúba (Goupia glabra Aubl.), Faveira folha-fina (Piptadenia suaveolens Miq.) e Piquiámarfim (Aspidosperma obscurinervium Azambuja), durante os processos de laminação, secagem e colagem.

Nos ensaios foram utilizadas duas toras por espécie, sendo que cada tora foi retirada de uma árvore, num total de 20 árvores, procedentes do município Presidente Figueiredo, Estado do Amazonas.

Foram testados uma regulagem para laminação, um programa de secagem e uma formulação de colagem e prensagem. Nas lâminas, mediu-se a rugosidade, a uniformidade de espessura, o número e profundidade das fendas de laminação, e a resistência a tração normal. $O$ compensado foi avaliado pela resistência ao cisalhamento e porcentagem de falhas na madeira. 
Em relação ao processo de lâminação verificou-se que as madeiras mais densas foram as que apresentaram maior rugosidade, maiores espessuras, menores números e maiores profundidades de fendas de laminação, e maior resistência a tração normal. Respectivamente os melhores resultados foram obtidos com as espécies Breu vermelho (Protium puncticulatum Macbr.), Cedrorana (Cedrelinga catenaeformis Ducke), Ucuúba branca (Osteophloeum platyspermum Warb.) e Faveira folha-fina (Piptadenia suoveolens Miq.). Na análise do compensado, as madeiras mais densas foram as que apresentam maior resistência ao cisalhamento e porcentagem de falhas na madeira, sendo os melhores resultados obtidos com as espécies Piquiámarfim (Aspidosperma obscurínervium Azambuja), Faveira folha-fina (Piptadenia suaveolens Miq.), Cupiúba (Goupia glabra Aubl.), Guariúba (Clarisia racemosa $\mathrm{R}$. et. Pay.) e Cedrorana (Cedrelinga catenaeformis Ducke).

Pelas características das lâminas verificou-se que é possível utilizar todas as espécies na produção de compensados, sendo que a qualidade da lâmina irá definir o seu uso como miolo, intermediária ou capa, tanto para uso interno e externo.

Conclui-se também que, para melhorar a qualidade das lâminas, é necessário ajustar a regulagem do torno em função da espécie a ser lâminada. 


\title{
TROPICAL SPECIES FOR \\ PLYWOOD MANUFACTURING
}

\author{
Author: Francisco Mota da Silva \\ Adviser: Prof. Dr. Ivaldo Pontes Jankowsky
}

\section{SUMMARY}

The objectives of this study were to evaluate the tropical wood species Ucuúba branca (Osteophloeum platyspermum Warb.), Cedrorana (Cedrelinga catenaeformis Ducke), Louro gamela (Nectandra rubra (Maz.) C. K. Allen), Breu vermelho (Protium puncticulatum Macbr.), Cardeiro (Scleronema micranthum Ducke), Guariúba (Clarisia racemosa R. et. Pay.), Piquiarana (Cariocar pallidum Aubl.), Cupiúba (Goupia glabra Aubl.), Faveira folha-fina (Piptadenia suaveolens Miq.) e Piquiá-marfim (Aspidosperma obscurinervium Azambuja), for veneer peeling and plywood manufacturing.

For the trial two trees for each species were felled, and it was used one $\log$ per tree.

All the logs were peeled according the same lathe settings and the plywood was manufactured under the same gluing and pressing conditions. Roughness, lathe checks, thicknees and strength to perpendicular tension were evaluated for veneer; and glue line shear strength and wood failure analised for plywood.

In relation to the peeling precess, it was observed that the veneer of dense species were more rough and thick, with deeper lather checks 
and higher strength to tension test. Respectively, the best results were obtained with the species Breu vermelho (Protium puncticulatum Macbr.), Cedrorana (Cedrelinga catenaeformis Ducke), Ucuúba branca (Osteophloeum platyspermum Warb.) e Faveira folha-fina (Piptadenia suoveolens Miq.). The plywood manufactured with veneer of dense species showed higher strength of glue line, and the best results were obtained with Piquiá-marfim (Aspidosperma obscurinervium Azambuja), Faveira folha-fina (Piptadenia suaveolens Miq.), Cupiúba (Goupia glabra Aubl.), Guariúba (Clarisia racemosa $\mathrm{R}$. et. Pay.) e Cedrorana (Cedrelinga catenaeformis Ducke).

All ten species tested can be use to plywood manufacturing, and the veneer quality will determe its use as face or core as well to interior or exterior plywood.

To improve veneer quality it is necessary to adjust the lathe settings according each one particular species. 


\section{INTRODUÇÃO.}

O Estado do Amazonas localiza-se na região Norte brasileira, entre os paralelos $2^{\circ} 15^{\prime} 30^{\prime \prime}$ de latitude Norte e $9^{\circ} 49^{\prime} 13^{\prime \prime}$ de latitude Sul e os meridianos $56^{\circ} 05^{\prime} 49^{\prime \prime}$ e $73^{\circ} 48^{\prime} 05^{\prime \prime}$ de longitude Oeste. Geograficamente é a região de ocorrência da floresta tropical, pois aí existem todas as condições climáticas ideais para este tipo de vegetação: luminosidade, umidade, temperatura, água, vento, além de solo e altitude (FLENLEY, 1979).

O Estado tem sua economia baseada principalmente na indústria e comércio de materiais eletro-eletrônicos da Zona Franca de Manaus e de produtos florestais, com destaque para a madeira. Dentre as indústrias madeireiras, a indústria de laminados e compensados é a que mais aloca mão-de-obra, responsável por $60 \%$ dos empregos no setor. Gera em torno de 2.615 empregos diretos, sendo $49,55 \%$ no interior e $50,44 \%$ na capital (SEBRAE, 1994).

Embora a primeira indústria de compensados no Estado do Amazonas tenha iniciado suas atividades na década de 50, só a partir dos anos 70 é que se verificou o aumento do parque industrial com o surgimento de novas empresas. Este fato foi consequência de uma resolução do Conselho Nacional do Comércio Exterior (Resolução CONCEX 86/1973), que proibiu a exportação de madeiras em toras e concedeu incentivos fiscais e creditícios para os investidores na Amazônia, e também devido a crescente demanda de madeiras tropicais para este tipo de produtos. 
A floresta amazonense é rica em espécies árboreas. Análise feita por PRANCE et alii (1976), em uma estrutura florestal próxima a Manaus, mostra a existência de 235 espécies lenhosas por hectare, em mata de terra-firme, com diâmetro igual ou superior a $5 \mathrm{~cm}$.

Esta grande heterogeneidade da floresta, aliada a alta dispersão das espécies, gera uma baixa densidade de uma mesma espécie por hectare. Este fato tem sido apontado pelos industriais do ramo como uma das causas principais para o não aproveitamento do recurso florestal.

A despeito das vantagens que a região oferece, para $o$ fortalecimento da indústria florestal, a mesma é ainda ineficiente, carente de atualização tecnológica e basicamente alicerçada no extrativismo, sem manejo ou reposição da matéria-prima florestal.

A matéria-prima utilizada na fabricação de laminados e compensados pelas indústrias da região constitui-se basicamente pelas espécies cuja madeira é considerada "mole" (densidade entre 0,3 e $0,5 \mathrm{~g} / \mathrm{cm}^{3}$ ). Dentro desta faixa, são preferidas aquelas que não necessitam de prévio aquecimento para serem laminadas (menores densidades), concentrando a exploração florestal em um reduzido número de espécies. Assim, muitas das espécies aptas para tais produtos são deixadas a apodrecer na floresta ou são sub-utilizadas, pelo falso conceito de elas não apresentam características próprias para a fabricação de laminados e compensados.

Visando aumentar as possibilidades de uso para espécies não tradicionais na indústria madeireira local, o presente trabalho teve como objetivo principal estudar dez espécies de madeiras da floresta amazonense quanto à possibilidade de uso na produção de laminados e compensados. 


\section{REVISÃO DE LITERATURA.}

\subsection{A produção de painéis compensados.}

A produção de laminados teve seu início provavelmente no antigo Egito, por volta de $3.000 \mathrm{AC}$, e eram utilizadas na fabricação de móveis finos, destinados a reis e príncipes (KOLLMANN \& CÔTĖ, 1968). Hoje este produto é utilizado principalmente na composição de compensados e revestimento de painéis para fins decorativos.

Compensado é um painel normalmente composto por um número impar de lâminas de madeira, obtidas através de tornos laminadores, coladas umas sobre as outras com adesivos apropriados, ficando a direção das fibras de cada uma destas folhas dispostas segundo ângulos determinados, sendo mais comum $90^{\circ}$, conforme é mostrado na Figura 1.

O sentido ortogonal das fibras, na formação do compensado, visa a redistribuição das propriedades físicas e mecânicas da madeira por ser a mesma um material anisotrópico, isto é, suporta grandes esforços paralelamente as fibras, enquanto que, em direção perpendicular as mesmas tem discreta atuação (SOUZA, 1962). 


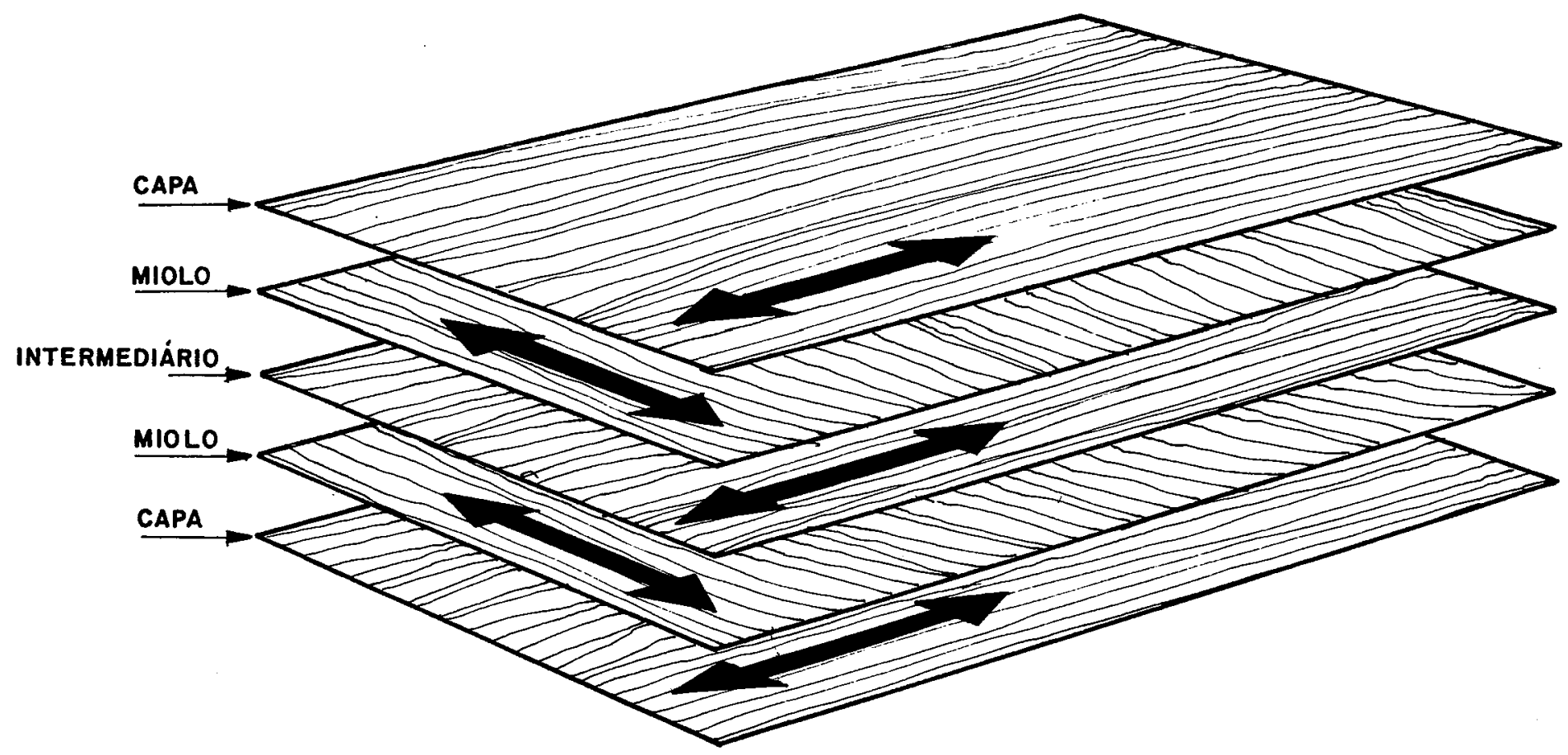

Figura 1. Composição do compensado mostrando a alternância da direção das fibras e a posição das lâminas de capa, miolo e intermediária.

As lâminas externas dos compensados são chamadas capas e as internas, cuja orientação das fibras é paralela às capas, são chamadas de intermediárias. A camada ou camadas internas, com as fibras no sentido perpendicular as anteriores, são chamada(s) miolo.

Lâminas são folhas finas de madeira, com espessura entre $0,3 \mathrm{~mm}$ e 6,0 mm (LUTZ, 1971), obtidas do tronco das espécies lenhosas através do corte em faqueadeiras, tornos rotativos ou serras.

Segundo LUTZ (1978), de uma maneira geral as folhosas são mais facilmente transformadas em lâminas que as coníferas. Isto atribui-se ao fato de 
que as folhosas respondem melhor aos esforços de flexão, produzindo lâminas menos danificadas por fendilhamentos. A razão parece estar relacionada ao maior conteúdo de lignina nas coníferas e ao fato de serem estas menos termoplásticas.

A densidade tem sido ao longo dos tempos a primeira propriedade a se ter conhecimento para se trabalhar com a madeira, e pode ser usada geralmente como uma variável para escolha de madeira destinada a produção de compensados. De um modo geral, as espécies que apresentam densidade compreendida entre 0,40 e $0,70 \mathrm{~g} / \mathrm{cm}^{3}$ são as preferidas para este tipo de produto (LUTZ, 1978).

FOCKEL et alii (1990), em seu estudo sobre a interdependência da densidade básica em relação algumas características físicas, químicas e anatômicas da madeira de espécies de Eucalyptus recomenda, a despeito de ser esta propriedade universalmente aceita como indicador de qualidade da madeira, cautela nas comparações entre espécies, quando baseadas simplesmente nesta propriedade.

O teor de umidade é outro fator de fundamental importância para que se obtenham lâminas de boa qualidade. No corte das lâminas, a tora é comprimida na frente do gume da faca, e quando o teor de umidade é muito alto a compressão pode fazer com que a água (praticamente incompressível) arrebente as fibras da madeira. Por outro lado, madeira com baixo teor de umidade resulta em lâminas rugosas e com excesso de fendas de laminação. Os melhores resultados foram obtidos com umidades compreendidas entre 50-60\% (LUTZ, 1978).

Segundo BRYANT et alii, citado por LUTZ (1967), a diferença no teor de umidade entre as partes de uma mesma tora, numa mesma condição de corte, afetam a uniformidade de espessura. As partes mais úmidas (alburno) 
resultam em lâminas mais finas do que aquelas obtidas das áreas menos úmidas (cerne).

A permeabilidade é um fator que tem influência nas operações de laminação, secagem e colagem. Uma madeira de boa permeabilidade pode diminuir o problema de eliminação de água durante a laminação, facilita a secagem e melhora as condições para a colagem pela eliminação do vapor da água desprendido durante a cura da cola LUTZ (1978).

Segundo o mesmo autor, a qualidade de uma boa lâmina inicialmente esta relacioanada com a uniformidade de espessura, superfície lisa com o mínimo de rugosidade, e que esta apresente-se sem ondulações após a secagem. Dependendo do uso a ser dado ao compensado, pode-se exigir na lâmina um controle de cor, figura, número e profundidade das fendas de laminação.

A qualidade da lâmina tambem é determinada com base em defeitos naturais como nós, rachaduras e presença de extrativos.

Segundo FEIHL \& GODIN (1970), a variação na espessura afeta a linhạ de colagem e o posterior processamento da lâmina; a rugosidade excessiva provoca um aumento no consumo de adesivo, prejudica a linha de colagem, e condiciona a quantidade de madeira que será retirada das faces do painel durante o lixamento.

Uma lâmina com fendas de laminação profundas, poderá romperse quando manipulada; sob variações bruscas de umidade poderá ocorrer a delaminação do painel compensado; ou ainda ocasionar o aparecimento de rachaduras de superfícies, indesejaveis em painéis cujas faces irão receber um acabamento mais aprimorado. Por outro lado, uma lâmina com fendas de laminação superficiais ou ausente não terá a flexibilidade suficiente para facilitar 
o manuseio durante a manufatura do compensado.

Uma lâmina poderá ser considerada de boa qualidade quando apresentar uma superfície sem rugosidade, espessura uniforme, e com fendas de laminação não profundas: o que pode ser conseguido através da regulagem correta do torno laminador e com o prévio aquecimento das toras.

Segundo FEIHL \& GODIN (1970), tornos desfolhadores são máquinas complexas designadas para trabalhos de precisão com recursos técnicos para fazer ajustes na ordem de um milésimo de polegada ou de um minuto de ângulo. Para que isso ocorra há necessidade de que quatro parâmetros básicos sejam alinhados de forma a produzir lâminas sem defeitos. Tais parâmetros são: 0 alinhamento do fio da faca com o centro das garras, ajustes das aberturas horizontal e vertical entre a barra de compressão e o fio da faca e o ajuste do ângulo da faca, conforme é mostrado na Figura 2.

A função da faca é a de cortar a madeira em lâminas e de separar estas lâminas da tora. $O$ ângulo de afiação da faca normalmente varia entre $18^{\circ} \mathrm{e}$ $23^{\circ}$. Quanto menor for o ângulo de afiação da faca, menos se curva a lâmina ao ser cortada, tornando esta menos resistente. Ao contrário, quanto maior for 0 ângulo de áfiação mais rígida é a lâmina e maior é a resistência do fio da faca aos impactos LUTZ (1974).

A medida que a faca avança em direção ao centro da tora que está girando, ela remove uma lâmina cilíndrica de madeira durante cada giro completo. Durante o processo de laminação, a curvatura natural da lâmina é eliminada. Esta retificação da lâmina, bem como o próprio processo de laminação, ocasionam o aparecimento de pequenas rachaduras na parte inferior da lâmina. Estas rachaduras são comumente denominadas fendas de laminação, de acordo com LIMBACH (1946). 


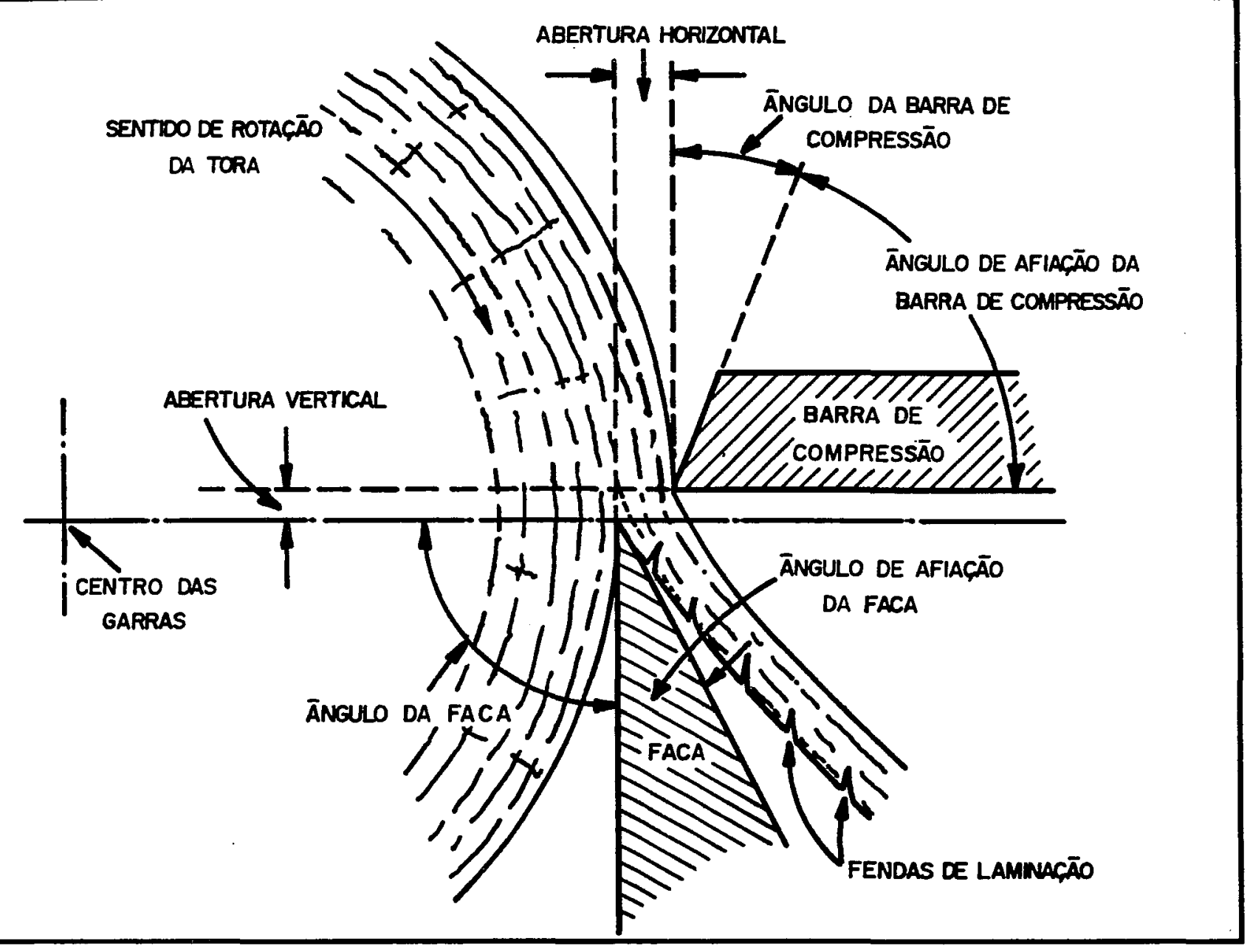

Figura 2. Relações geométricas entre a tora, a faca e a barra de compressão.

O fio da faca é muito importante para o controle da rugosidade das lâminas, uma faca cega combinada com altas compressões na barra de pressão favorece o arrebentamento da parede celular pela água ocasionando o surgimento de rachaduras na parte superior da lâmina (LUTZ, 1978).

Já a função da barra de compressão é comprimir ligeiramente a madeira diante do gume da faca. Esta compressão controla a qualidade em têrmos de rugosidade, profundidade das fendas de laminação e uniformidade de 
espessura LUTZ (1974).

A posição relativa da barra de compressão e a faca determinam três aberturas, as quais são, as aberturas horizontal e vertical e a abertura de saída da lâmina. Se fixarmos duas destas aberturas, automaticamente a terceira será fixada. A abertura vertical primeiramente é ajustada em relação a espessura nominal da lâmina, alguns operadores de torno fixam esta abertura como sendo $1 / 3$ da espessura da lâmina. $O$ valor da abertura horizontal, como a anterior, depende da espessura da lâmina e até certo ponto da espécie que será laminada (LUTZ, 1974).

Usualmente é mencionado que a abertura horizontal deve ser $20 \%$ menor que a espessura da lâmina. No entanto tem se encontrado que uma compressão entre $10 \%$ e $15 \%$ são adequadas para cortar lâminas entre $1,6 \mathrm{~mm}$ e $3,2 \mathrm{~mm}$. de espessura. Uma compressão maior pode resultar em lâminas mais finas do que a espessura nominal ou com fibras arrancadas no lado superior das lâminas LUTZ (1974).

Segundo LUTZ (1960), USDA (1962) \& FAO (1968), o aquecimento tem como finalidade facilitar a remoção da casca com ferramentas manuais, tornar a madeira mais plástica, facilitar o corte, aumentar a vida útil da faca e melhorar a qualidade da lâmina ao diminuir a rugosidade e a profundidade das fendas de laminação.

$\mathrm{O}$ aquecimento também apresenta defeitos negativos; aumenta as rachaduras de topo das toras e se realizado a altas temperaturas e por longos períodos de tempo, pode afetar as propriedades de resistência da madeira. GREENHILL, citado por LONDOÑO (1970), em seu estudo sobre a relação entre a temperatura e o teor de umidade com respeito as propriedades da madeira, encontrou que a $82^{\circ} \mathrm{C}$ a resistência na flexão estática, o módulo de ruptura e o 
módulo de elasticidade são reduzidos a um terço do valor obtido a temperatura ambiente.

O aquecimento da tora pode levar ao desgarre no topo da tora pelo torque do torno durante a laminação. $\mathrm{Na}$ realidade, a causa disto na maioria das vezes é a não equalização da temperatura na tora. Estando o topo mais quente e mais mole que a parte central, em consequência, a força de corte necessária será maior no centro, é este gradiente final de forças o responsável pelo desgarre do topo (LUTZ, 1978).

Após o corte as lâminas devem ser submetidas a secagem, uma das etapas de maior importância dentro do processo de fabricação de compensados. No que se refere à economia nas etapas de produção, COMSTOCK (1971) considera que o maior consumo de energia, em todos os processamentos primários da madeira, ocorre durante a sua secagem, onde é utilizado de 60 a $70 \%$ do total da energia consumida.

Já a importância de uma adequada secagem de lâminas na qualidade das mesmas e, posteriormente, na qualidade dos compensados é de induscutível aceitação, conforme tem sido comentado por diferentes autores como BLOOMQUIST (1966), KOCH (1972), CHOW (1973), KOLLMANN et alii (1975) \& TOMASELLI (1983).

As variáveis que influenciam o tempo de secagem e/ou a qualidade das lâminas após a secagem são aquelas referentes a lâmina, que incluem a espécie de madeira, sua espessura e densidade, o tipo de madeira (cerne ou alburno) e o teor de umidade inicial e final; e as variáveis referentes ao processo que incidem principalmente na temperatura, umidade relativa e a velocidade do ar. Segundo COMSTOCK (1971), outras variáveis podem ser acrescentadas a cada uma destas categorias, porem as variáveis citadas são consideradas como as 
de maior influência

KOCH (1972), discute a influência do teor de umidade inicial na secagem de madeiras a temperaturas inferiores a $100^{\circ} \mathrm{C}$, concluindo que o tempo total de secagem da madeira aumenta com o aumento do teor de umidade inicial, tanto para madeiras altamente permeáveis quando a remoção da umidade da superfície é o fator limitante, como para madeiras altamente impermeáveis caso em que a difusão da umidade se constitue no fator limitante e praticamente, nenhum movimento de água livre ocorre. Em temperaturas superiores a $100^{\circ} \mathrm{C}$, o efeito da permeabilidade aumenta, pois as aberturas celulares alem de terem fundamental importância no primeiro estágio da secagem para o escoamento ou a evaporação da água livre, mantem esta importância no segundo estágio para o escoamento hidrodinâmico (movimento da umidade sob pressão).

Estudos apresentados por LUTZ (1974), indicam que a densidade das lâminas pode ser um fator que influência no tempo total de secagem, sendo que as mais densas requerem maior quantidade de calorias para aquecer e secar do que as menos densas.

Da mesma forma que para a densidade, COMSTOCK (1971) considera o cerne e o alburno como variáveis de secagem, somente no que se refere a diferença entre suas densidades e teor de umidade.

O teor de umidade inicial das lâminas é bastante variável em função da espécie de madeira, do tipo de madeira (cerne ou alburno), e do aquecimento com água ou vapor, utilizado antes de se realizar o torneamento. Segundo KOLLMANN et alii (1975), este teor de umidade varia de $30 \%$ a $100 \%$, baseando-se na massa da madeira seca.

Esta grande variação no teor de umidade inicial constitui-se em um problema constante na secagem de lâminas, uma vez que, em consequência, uma 
grande variação de tempo ocorre para secar diferentes lâminas até um determinado teor de umidade final, dificultando o estabelecimento de um programa adequado de secagem. Assim, WALTERS citado por KOCH (1972), aconselha a seleção de lâminas de acordo com a quantidade de água por unidade de volume da lâmina verde, afim de se conseguir uma secagem mais uniforme e um aumento na produção de lâminas secas.

Segundo CHOW et alii (1974) citado por MEDINA (1986), entre os problemas de secagem de madeiras que mais afetam a uniformidade da umidade final, temos a diferença no conteúdo de umidade inicial entre as madeiras de cerne e alburno; uma separação destas duas para serem secadas separadamente com programas diferentes é a chave no exito da secagem. $O$ problema todavia não é tão simples, devido ao fato que toras cônicas torneadas produzem, em grandes proporções, lâminas que possuem na mesma folha madeiras do cerne e alburno.

$\mathrm{Na}$ maioria dos processos de secagem da madeira e de seus produtos, duas variáveis são controladas, a temperatura e a umidade relativa. $\mathrm{O}$ aumento da temperatura diminui o tempo de secagem das lâminas, e embora se deva operar a temperaturas tão altas quanto possível, deve-se observar os limites toleráveis impostos pela qualidade final das lâminas. Lâminas ressequidas podem apresentar mudanças na sua coloração, como tambem a inativação de sua superfície o que conduz a uma diminuição das forças de adesão entre a cola e a madeira. Em lâminas secas a $200^{\circ} \mathrm{C}$ e que apresentam superfícies ressequidas, a porcentagem de falha na madeira diminui e aumenta a porcentagem de falha na linha de cola, o que significa baixa qualidade da colagem (BLOOMQUIST, 1966).

A influência da velocidade do ar no tempo de secagem é bem 
conhecida e tem sido relatada por diversos autores, conforme comentado por TOMASELLI (1977). O ar é responsável pela transferência de calor da fonte de aquecimento para a superfície da madeira, e pela transferência da massa de vapor da água da superfície da madeira para o exterior.

A influência da circulação do ar no tempo de secagem é mais importante a altas temperaturas do que nos processos convencionais. Nestes últimos processos a influência da velocidade do ar decresce nitidamente com a aproximação do ponto de saturação das fibras, enquanto na secagem a altas temperaturas esta influência continua a ter importância para teores de umidade bem abaixo deste ponto, segundo KOLLANN \& SCHNEIDER também citados por TOMASELLI (1977).

\subsection{Relação entre a matéria-prima, o processo e o produto.}

A madeira é um material proveniente do tronco de vegetais superiores, formado por um conjunto de células com propriedades específicas para desempenhar as funções vitais de crescimento, condução de água, transformações, armazenamento, e condução de substâncias nutritivas, assim como, sustentação do vegetal (KRAMER \& KOZLOWSKI, 1972).

O tronco das árvores é constituido, como indicado na Figura 3, pelas seguintes partes, que excetuando-se o câmbio e na maioria dos casos, os raios, destacam-se: 


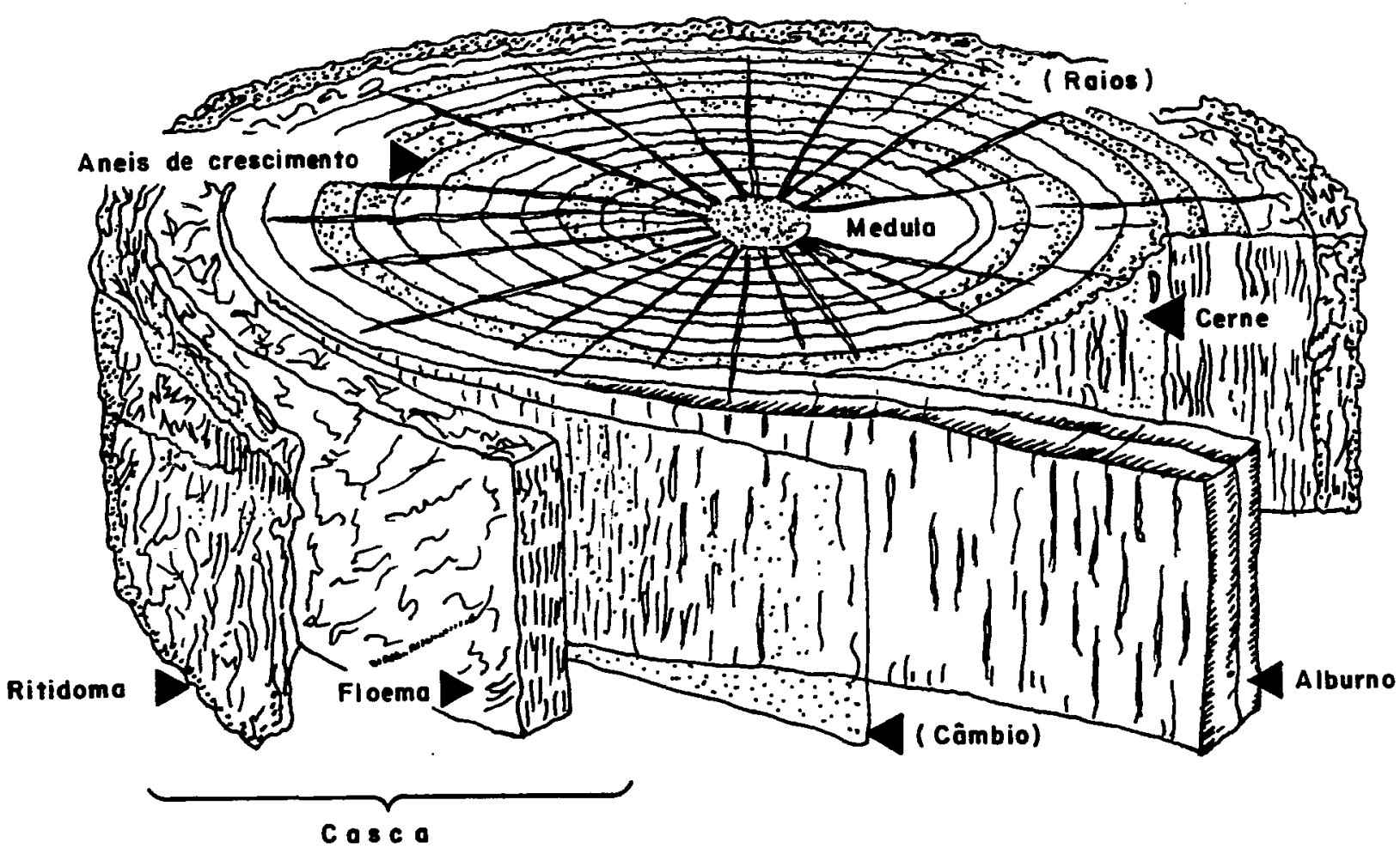

Figura 3. Representação esquemática macroscópica de uma seção do tronco.

Medula: É indicada por um pequeno núcleo central do fuste. Representa o crescimento primário e desempenha a função de armazenar substâncias nutritivas no período de crescimento primário das árvores. Por se tratar de um tecido parenquimático de pouca densidade, a medula é uma região susceptível a apodrecimentos causados por fungos.

Cerne: É a parte interna do lenho, originária da morte gradual do tecido do alburno, constituido por células já sem atividade vegetativa. Apresenta frequentemente óleos, gomas, resinas, taninos e outras substâncias que o torna mais escuro e durável que o alburno, dá resistência ao tronco. 
Alburno: É a parte externa do lenho, as suas células armazenam alimento e transportam água e minerais. As suas células vivas fazem parte ativa no processo metabólico, como respiração e digestão. Caracteriza-se por ser mais permeável e apresentar coloração mais clara que o cerne.

Raios: São faixas de células parenquimáticas dispostas horizontalmente no tronco ligando diversas camadas, e desempenham a função de armazenagem e condução de substâncias nutritivas.

Anéis de crescimento: É cada camada do tecido lenhoso formada num período de vegetação. Serve como regra geral para se determinar a idade de uma árvore, e se esta apresenta incremento rápido (anéis largos), ou incremento lento (anéis estreito) e quais anos foram desfavoráveis ao seu crescimento, particularmente em madeiras de clima temperado.

Casca: É todo o tecido da árvore que fica fora do cilindro da madeira. É divisível, geralmente nas árvores adultas e velhas, em uma parte externa e morta, denominada casca externa ou ritidoma, e uma parte interna viva, que recebe o nome de floema ou liber. Tem como função, dar proteção a árvore, alem da condução de nutrientes feito pelo floema.

Segundo LUTZ (1978), a madeira ideal para laminados e compensados, é aquela que apresenta um bom formato cilindrico e seja concêntrica, isto é, que a medula esteja localizada no centro geométrico da tora. A casca deve ser facilmente removida sem deixar defeitos. Apresentar boa sanidade, com as camadas de crescimento e textura uniforme. A densidade da espécie deve ser mediana entre 0,40 a $0,70 \mathrm{~g} / \mathrm{cm}^{3}$. A grã deve ser reta. Sua anatomia deve ser homogênea.

No entanto, a madeira por ser um produto natural, esta sujeita a sofrer uma série de defeitos que em conjunto com as características da própria 
madeira, podem limitar tecnicamente o seu uso em laminados e compensados. Por outro lado, certas características intrínsecas da madeira são desejáveis na fabricação destes produtos por possuirem usos específicos.

Conicidade: É uma características anômala na forma do tronco, caracteriza-se pela diminuição excessiva do diâmetro da base da árvore para copa. A conicidade ocorre principalmente, em árvores isoladas, ou naquelas situadas às margens de povoamentos. De um modo geral, os troncos são classificados como cônicos quando a diminuição do seu diâmetro importa em mais de $1 \mathrm{~cm}$ por metro de comprimento (da base em direção a copa) (GROSSER, 1980). A conicidade das árvores, que tambem pode ser diminuida pela técnica de manejo sivicultural, afeta a qualidade das lâminas obtidas por meio de laminação rotativa; as lâminas resultam com grã curtas o que acarreta debilídade ao flexionamento e a contração longitudinal, além de apresentar uma grande variação no teor de umidade final (LUTZ, 1978 e CHOW et alii, 1974).

Tronco curvo: caracteriza-se pelo desvio da forma reta do tronco (curvatura). $\mathrm{Na}$ fabricação de compensados assim como a conicidade, este defeito apresenta-se como de ordem econômica e técnica. Economicamente, por não permitir o aproveitamento real do seu volume, pois até que a tora fique cilíndrica na operação de desbaste, é desperdiçada muita matéria-prima, e tecnicamente pelas lâminas apresentarem os mesmos defeitos observados em madeiras cônicas.

Troncos excêntricos: são caracterizados pela medula estar localizada fora do centro geométrico da tora. Como a garra do torno tem que ficar no centro geométrico da tora, isto gera lâminas bastantes rugosas, visto que, a cada revolução de corte da tora, a faca fica disposta contra a grã dos anéis de crescimento, ao contrário do que ocorre no corte de uma madeira concentrica (LUTZ, 1978). Se por outro lado, a garra do torno for presa no meio do topo de 
uma tora excêntrica, haverá uma grande perda de madeira por ocasião do desbaste, ocasionando perdas de ordem econômica.

Tronco sulcado: é um desvio da forma do tronco, que se evidencia com o envelhecer da árvore, conferindo a sua periferia um contorno sinuoso e irregular (dependendo da espécie, as sinuosidades serão arredondadas ou agudas). Os sulcos podem se estender por todo o tronco, ou limitar-se a sua parte basal (GROSSER, 1980). Como nos casos anteriores há uma perda muito grande de matéria-prima, por ocasião do desbaste, até que a tora adquira um formato cilindrico.

Lenho de reação: São originários de árvores cujos os troncos se desviaram da direção normal de crescimento em consequência de qualquer ação externa. Dependendo da intensidade, tempo e sentido, originam tipos especiais de lenho. Não chega a ser um defeito limitante para o uso deste tipo de madeira na produção de compensados. Todavia, quando a madeira é torneada, produz lâminas com características física e mecânicas excessivamente heterogênea, apresentando partes lisas e partes rugosas. Isto ocasiona uma instabilidade dimensional e tendência ao empenamento das lâminas durante a secagem. Estas características são indesejáveis na produção de um bom compensado (LUTZ, 1978).

Rachaduras de topo: São fendas típicas existentes nos topos das toras após a derrubada das árvores, provenientes das tensões naturais de crescimento associadas ao processo de secagem e/ou aquecimento. As rachaduras de topo aparecem, geralmente nos raios que são constituidos por células parenquimáticas de reduzidas resistência mecânicas. São consequencia da diferença entre as retrações tangencial (maior) e radial (GALVÃo \& JANKOWSKY, 1988). Segundo LUTZ (1978), quando a madeira verde começa a aquecer-se, a partir de $60^{\circ} \mathrm{C}$, esta se espande tangencialmente e se contrai 
radialmente, aumentando estas rachaduras. Quando trabalhamos com madeiras que apresentam acentuadas propensões a rechaduras, geramos duas perdas. A primeira porque temos que eliminar a parte rachada antes do torneamento, e a segunda, porque as lâminas ao secar voltam a apresentar rachaduras nas suas extremidades.

A textura tem grande importância face à colagem de lâminas de madeiras para compensados. Madeiras com textura grossa tendem a uma excessiva absorção de adesivo, que pode causar má colagem e ultrapassagem da cola até a outra face da lâmina. Ao contrário, madeiras de estrutura muito fechada e superfície lisa, devido a deficiência de penetração do adesivo, apresentam frequentemente uma linha de cola fraca (BURGER \& RICHTER, 1991).

A presença de nós é um fator determinante quanto à qualidade da madeira para laminados e compensados. Dependendo da sua sanidade, inserção, forma, localização, dimensão e agrupamento, eles dão ao laminado uso específicos, como lâminas destinadas a fins decorativos, onde a figura realçante dos nós é requerida, podendo tambem em outros casos serem aceitos em lâminas de uso interno e/ou externo em painéis de uso geral, como por exemplo, divisórias e engradados. Madeiras que possuem nós densos, ao serem torneadas causam danos à faca e aumentam a rugosidade das lâminas (LUTZ, 1978).

Além da celulose, hemicelulose e lignina, outras substâncias se fazem presentes na madeira e, embora não fazendo parte direta da sua estrutura, influenciam em algumas de suas propriedades como cor, cheiro e resistência ao apodrecimento. Eles formam grupos, em geral, a parte, de materiais estranhos e incluem taninos, óleos excênciais, resinas, ceras, depósitos minerais e outros similares (LUTZ, 1978).

Tais substâncias podem causar dificuldades nas operações de 
manufatura do compensado. Um caso típico neste aspecto, é a presença de depositos minerais como carbonato de cálcio e sílica, substâncias que apresentam elevadíssimo grau de dureza e que quando presente em grande abundância, são capazes de tornar anti-econômico o aproveitamento da madeira, pelos danos que causam nos equipamentos (BURGER \& RICHTER, 1991).

SOBRAL FILHO (1982), revisando trabalhos sobre adesão e adesivos em relação a madeira, concluí que a formação de uma colagem adequada a sua performance em serviço dependem principalmente dos parâmetros relacionados as características físicos-químicas do adesivo, características do substrato (material a ser colado), e procedimentos usados na colagem.

Segundo o autor o conhecimento do material madeira é ainda relativamente restrito, e o que se sabe da adesão e colagem da madeira ainda permanece parcialmente como uma arte, apesar da considerável soma de pesquisas devotadas a este campo nos últimos anos. Algumas das mais importantes características da madeira que afetam a adesão e colagem são:

Variabilidade: Não existem duas peças de madeira iguais. As variações (na estrutura anatômica, composição química, propriedades físicas e mecânicas, ets.) de maior grandeza ocorrem entre espécies, sendo conhecimento comum que umas espécies são mais fáceis de colar do que outras. A natureza biológica da madeira causa adicionalmente amplas variações entre árvores de uma mesma espécie, e mesmo no material de uma mesma árvore. Esta variabilidade atinge uma série de propriedades (peso específico, textura, permeabilidade, etc.), que por sua vez são determinantes no processo de adesão e na performance da colagem.

Densidade: Existem fortes indicações de que colagens feitas em madeiras de alta densidade degradam-se mais rapidamente do que colagens 
efetuadas em madeiras de baixa densidade. Além disto, madeiras mais densas, normalmente possuem maior resistência mecânica, exigindo assim, linhas de colas que possam resistir à tensões superiores às exigidas para madeiras menos densas. A densidade da espécie madeireira está tambem diretamente relacionada com a sua porosidade e permeabilidade, influenciando assim o grau de rugosidade (devido a estrutura anatômica) e as funções de mobilidade, fatores determinantes na formação da ligação adesivo-substrato.

Anisotropia: Os planos principais de colagem (tangencial e radial) representam superfícies com diferentes estruturas anatômicas, composição químicas e, mesmo, superfícies físicas, implicando em inter-relações com o adesivo, o que, obrigatoriamente, reflete-se na colagem e linha de cola.

Porosidade e permeabilidade: $O$ tamanho, disposição e frequência de cavidades celulares e poros na estrutura da madeira afetam diretamente a penetração do adesivo. As interações da porosidade e permeabilidade com a migração do solvente tambem interferem na viscosidade da resina, afetando suas funções de mobilidade, o que, obviamente, acarreta mudanças na qualidade da colagem.

Extrativos: A presença de extrativos na madeira de algumas espécies frequentemente constitu-se em obstáculo ao desenvolvimento de uma boa colagem. Extrativos e outros contaminantes da superfície podem causar um decréscimo do umedecimento, levando a uma colagem de qualidade inferior. Os extrativos da madeira podem ainda interferir com a reação de polimerização do adesivo, a prévia extração de resinas e outros extratos de algumas espécies contribui sensivelmente para facilitar sua colagem.

Alburno e Cerne: Para a maioria das espécies, as funções de mobilidade do adesivo no alburno e no cerne diferem, principalmente devido a 
presença de extrativos e a menor porosidade e permeabilidade do cerne.

Lenho primaveril e Lenho tardio: As diferenças na espessura da parede celular e na densidade do lenho primaveril e lenho tardio influem decisivamente na colagem. As madeiras de países de clima temperados as células do lenho primaveril tem uma área capilar cerca de 10 vezes maior que celulas do lenho tardio.

pH e capacidade tampão: a maior parte das madeiras apresenta um $\mathrm{pH}$ levemente ácido. As variações de $\mathrm{pH}$ e capacidade tampão afetam diretamente a cura e a solidificação do adesivo, uma vez que estes processos normalmente ocorrem somente em faixas relativamente estritas de $\mathrm{pH}$.

Topografia da superfície: $O$ grau de proximidade que duas peças de madeira podem atingir, o qual é em parte determinado pela topografia das superficies, é fundamental para o processo de colagem. Asperezas e imperfeições na superfície da madeira são aspectos determinantes da fluidez, umedecimento, penetração e transferencia do adesivo.

Teor de umidade: $\mathrm{Na}$ colagem da madeira com os tradicionais adesivos sintéticos à base de uréia, melamina, fenol e resorcinol, é imprescíndivel que a madeira seja previamente seca até teores de umidades normalmente variando entre $6 \%$ e $12 \%$. Teores de umidades mais altos geralmente implicam em linhas de cola menos resistentes, alem de envolverem riscos de formação de bolhas e delaminação.

O compensado é um produto basicamente destinado a dois tipos de usos, compensado para uso interno e compensado para uso externo. A diferenciação consiste normalmente no tipo de adesivo utilizado. A princípio, os compensados fabricados com adesivos a base de uréia-formaldeídos são destinados a usos internos, já aqueles fabricados com adesivo de base fenol- 
formoldeídos se destinam a usos externos.

Neste estudo, interessa-nos apenas compensados destinados a uso externo, que segundo as normas do INSTITUTO BRASILEIRO DE DESENVOLVIMENTO FLORESTAL (IBDF/1985) e da NATIONAL BUREAU OF STANDARDS (1972), são aqueles altamente resistentes a intempéries, microorganismos e à água fria ou quente.

$\mathrm{O}$ controle de qualidade da junta colada é feito através dos testes conhecidos como resistência da colagem ao esforço de cisalhamento e falha na madeira, prescritos nas normas citadas. Estes testes são realizados sob diferentes condições, as quais são, corpos de prova a seco, corpos de prova umedecido com água fria e após imersão em água fervente. A avaliação consiste em comparar os resultados obtidos com os exigidos pelas normas.

\subsection{A utilização de espécies tropicais na manufatura de compensados.}

LONDOÑO (1970), pesquisou a adaptação do Chupon (Pouteria aff. P. anibifolia), para a produção de laminado por corte rotatório e compensados manufaturado com adesivo à base de uréia-formaldeído. A madeira do chupon é considerada dura e pesada, densidade básica $0,70 \mathrm{~g} / \mathrm{cm}^{3}$, grã irregular com textura de mediana a fina. Utilizou neste estudo 8 toras desta espécie e manteve como condições fixas a espessura nominal das lâminas em $3,18 \mathrm{~mm}$ ângulo de afiação da faca $21^{\circ}$, ângulo da faca $90^{\circ}$, abertura vertical $0,762 \mathrm{~mm}$ e velocidade de corte de $60 \mathrm{~m} / \mathrm{min}$. Como variáveis, utilizou diferentes temperaturas de aquecimento $\left(50^{\circ} \mathrm{C}, 60^{\circ} \mathrm{C}, 70^{\circ} \mathrm{C}\right.$ e $\left.80^{\circ} \mathrm{C}\right)$, e diferentes compressões de barra $(25 \%, 20 \%, 15 \%$ e $10 \%)$. A avaliação das lâminas foi feita, principalmente, pela uniformidade de espessura, rugosidade, resitência a tração 
perpendicular à grã e número e profundidade das fendas de laminação, enquanto o compensado teve sua avaliação através do teste de resistência ao cisalhamento a seco e delaminação em água fria.

Segundo conclusões do autor, as lâminas de melhor qualidade foram obtidas no corte com temperatura de $80^{\circ} \mathrm{C}$ e compressão de barra de $20 \%$, exceto no caso da uniformidade de espessura, onde os melhores resultados foram obtidos com compressão de $15 \%$. Nas melhores condições, as lâminas apresentaram boa resistência a tensão perpendicular a grã, superfície lisa, menor número e profundidade de fendas de laminação e boas características de colagem.

CHUNG (1979), realizou um trabalho destinado a determinar a influência da compressão de barra, ângulos de faca $e$ temperaturas de aquecimento das toras, sobre a qualidade das lâminas produzidas por corte rotatório e do compensado com elas fabricadas. Neste estudo, o autor utilizou 24 toras procedentes de 8 árvores da espécie Terminalia amazonia (Gmel) Exell. Madeira considerada dura e pesada, peso específico aparente $0,82 \mathrm{~g} / \mathrm{cm}^{3}$ a $12 \%$ de teor de umidade, grã entrecruzada e textura média.

Manteve como parâmetros fixos a espessura nominal das lâminas em 2,0 mm, a abertura vertical da barra em 0,508 $\mathrm{mm}$ e o ângulo de afiação da faca em $21^{\circ}$. Como condições variáveis, utilizou a abertura horizontal $10 \%, 15 \%$ e $20 \%$ menor que a espessura nominal, ângulo de faca inicial de $89^{\circ} 20^{\prime} ; 89^{\circ} 40^{\prime}$; $90^{\circ} 00^{\prime} ; 90^{\circ} 20^{\prime} ; 90^{\circ} 40^{\prime}$ e $91^{\circ} 00^{\prime}$, e temperaturas de corte de $20^{\circ} \mathrm{C} ; 40^{\circ} \mathrm{C}$; $60^{\circ} \mathrm{C}$; e $80^{\circ} \mathrm{C}$. A avaliação das lâminas foi feita considerando a uniformidade de espessura, rugosidade, resistência à tensão perpendicular à grã, e número e profundidade das fendas de laminação. O compensado produzido com cola à base de uréia-formaldeido foi avaliado pelo teste de resistência ao cisalhamento e falha na madeira. 
Ao final de seus estudos, o autor concluiu que as melhores condições de corte foram obtidas com uma compressão de $20 \%$ da barra, $60^{\circ} \mathrm{C}$ de temperatura de aquecimento e o ângulo da faca de $90^{\circ} 40^{\prime}$. Nestas condições, com base nos parâmetros utilizados nas avaliações, tanto as lâminas quanto os compensados produzidos, apresentaram os melhores resultados após as interações das variáveis.

DELGADO (1976), estudou o comportamento de 23 espécies tropicais da Venezuela para a produção de lâminas por corte rotatório e secagem a jato sob alta temperatura, com o objetivo de classifica-las quanto ao uso específico e alternado em painéis compensados. Neste estudo foram utilizadas 8 toras por espécie sobre as quais incidio a metodologia geral da pesquisa, a qual consistio em manter fixo o ângulo de afiação da faca em $21^{\circ}$ e a temperatura de secagem em $150^{\circ} \mathrm{C}$. Os parâmetros váriaveis foram tempo e temperatura de aquecimento (Mín. $14 \mathrm{~h}$ a $60^{\circ} \mathrm{C}$ - Máx. $74 \mathrm{hs} \mathrm{a} 92^{\circ} \mathrm{C}$ ), ângulo da faca (Mín. $89^{\circ} 30^{\prime}$ - Máx. $90^{\circ} 30^{\prime}$ ). A avaliação foi feita com base nas características gerais das espécies, facilidade ou dificuldade em tornear e os defeitos produzidos pela secagem, como contração tangencial, retidão da superfície e laterais, aumento das fendas e descoloração das lâminas.

Segundo o autor, das 23 espécies estudadas 3 foram descartadas face ao mau formato das toras, nós duros com cristais, rachaduras de topo acentuadas e suscetibilidade a deterioração por agentes biológicos. Das restantes, 12 se mostraram aptas para serem utilizadas em compensados de uso geral e estrutural, 7 mostraram aptidão para uso em painéis decorativos e 6 apresentaram características próprias para serem usadas como miolo e intermediárias em compensados.

TOMASELLI (1992), desenvolveu um estudo com 22 espécies 
florestais de terra-firme e várzea, coletadas no estado do Pará e Amazonas e testadas em uma fábrica de compensado em cada estado. O trabalho visou a introdução de espécies pouco conhecidas nas indústrias de compensados da Amazônia. O estudo estabeleceu como um dos objetivos básico, a condução de análises técnicas segundo critérios como propriedades das madeiras, experiências já disponíveis na área de laminação, secagem e colagem de lâminas, e requerimentos básicos do produto final. Neste processo considerou-se como espécies adequadas a inclusão no estudo, aquelas que possuiam características físicas e mecânicas que a indicasse como adequadas a produção de lâminas, bem como a forma e o porte da árvore. A transformação das toras em lâminados e compensados, seguiu-se o processo normal sem que fosse introduzido qualquer alteração técnica no processo produtivo das indústrias. A avaliação consistiu na comparação do rendimento e das propriedades física (massa específica) e mecânicas (cisalhamento e flexão estática) das novas espécies com as atuais de mercado.

Segundo o autor, nenhuma das chapas testadas teve problema de delaminação, indicando que em princípio não existem problemas mais graves de colagem que inviabilizem o uso das espécies testadas para compensados. Por outro lado, 7 destas espécies apresentaram graves problemas na produção relacionados as características intrínsecas das madeiras como tensões internas que provocam excessivas rachaduras, baixas resistências causando o desbitolamento das lâminas, nós grandes, grã revessa, odor forte e desagradável, que em conjunto causam a redução no rendimento e dificuldades na produção o que praticamente inviabilizam estas espécies para uso em compensados.

SILVA (1989), com a finalidade de introduzir novas madeiras amazônicas nas indústrias de laminados e compensados da região, estudou o 
comportamento de 12 espécies madeireiras do estado do Amazonas, em pesquisa descritiva relacionada com as características aparentes das toras e seu comportamento ao serem torneadas, secadas e coladas, visando seu uso específico ou alternado na fabricação de compensados. Foram ensaiadas quatro toras por espécie, sendo duas por árvores distintas, tomou como parâmetros fixos o ângulo de afiação da faca em $20^{\circ}$, a temperatura de secagem em $160^{\circ} \mathrm{C}$ e a velocidade de secagem das lâminas em $1 \mathrm{~m} / \mathrm{min}$. Os parâmetros variáveis foram o ângulo da faca (mín. 90 $00^{\prime}$ - máx. $91^{\circ} 00^{\prime}$ ), a compressão de barra (mín. 10\% - máx. 15\%) e a espessura nominal das lâminas (mín. 1,6mm - máx. 3,2mm). A avaliação das lâminas foi feita com base no aplainamento da superfície e dos bordos, rugosidade, uniformidade de espessura, contração tangencial, incremento das fendas de topo, aparência estética, consistência e descoloração. A avaliação do compensado foi feita em função da resistência ao cisalhamento e falha na madeira. 


\section{MATERIAIS E MÉTODOS.}

\subsection{Espécies utilizadas.}

O material de ensaio foi coletado na área projetada para ser inundada pela hidrelétrica de Balbina, no rio Uatumã, município de Presidente Figueiredo, localizado ao norte da cidade de Manaus, entre as coordenadas geográficas $1^{\circ} 00^{\prime}$ e $2^{\circ} 00^{\prime}$ de latitude Sul, $59^{\circ} 20^{\prime}$ e $60^{\circ} 30^{\prime}$ de longitude Oeste (INPA, 1983).

A área em questão encontra-se na região fito-ecológica da floresta tropical densa, sendo dominada pela sub-região da superfície dissecada do complexo guianense e seguida pela sub-região dos interflúvios tabulares do planalto dissecado norte da Amazônia (DNPM/RADAM BRASIL, 1976).

De acordo com a classificação de Koppen, essa área é denominada pelo grupo climático A (clima tropical chuvoso), onde predomina o tipo climático Am com variação para $\mathrm{AmW}$. A temperatura média anual oscila em torno de $26^{\circ}$ $\mathrm{C}$, com pequena amplitude térmica, e a umidade relativa é sempre superior a $80 \%$.

Foram utilizadas as madeiras de Piquiá-marfim (Aspidosperma obscurinervium Azambuja), Piquiarana (Cariocar pallidum Aubl.), Cupiúba (Goupia glabra Aubl.), Faveira folha-fina (Piptadenia suaveolens Miq.), Cedrorana (Cedrelinga catenaeformis Ducke), Breu vermelho (Protium puncticulatum Macbr.), Cardeiro (Scleronema micranthum Ducke), Guariúba 
(Clarísia racemosa R. et. Pay.), Louro gamela (Nectandra rubra (Mez.) C. K. Allen) e Ucuúba branca (Osteophloeum platyspermum Warb.).

De cada espécie foram utilizadas duas toras, sendo cada tora proveniente de uma árvore distinta. As toras foram cortadas com 4,0 metros de comprimento e identificadas com um número sequencial de derrubada. Ao chegarem ao laboratório, eram seccionadas num comprimento de 2,0 metros. Uma destas toras era destinada aos estudos de laminados e compensados, sendo a outra destinada a anatomia e ensaios físicos-mecânicos, como a densidade básica.

A Tabela 1 apresenta as características gerais das madeiras utilizadas, e nas Tabelas 2 e 3 constam as características e os defeitos das toras destinadas aos ensaios de laminação.

Antes de serem processadas as toras permaneceram armazenadas em água por um período de 3 a 8 meses, em função das limitações físicas do laboratório.

A densidade básica das madeiras foi feita no laboratório de engenharia da madeira do CPPF/NPA, com base na massa seca do corpo de prova a zero por cento de umidade, dividida pelo seu volume saturado de acordo com a norma COPANT (1971). 
Tabela 1. Características gerais das madeiras, com base em LOUREIRO et. al. (1979).

\begin{tabular}{|c|c|c|c|c|c|c|}
\hline Espécie & $\begin{array}{l}\text { Densida- } \\
\text { de básica } \\
\left(\mathrm{g} / \mathrm{cm}^{3}\right)\end{array}$ & $\begin{array}{l}\text { Cor do } \\
\text { Cerne }\end{array}$ & Grã & Textura & Cheiro & Gosto \\
\hline $\begin{array}{l}\text { Ucuúba branca } \\
\text { (Osteophlocum platyspermum } \\
\text { Warb.) }\end{array}$ & 0,42 & $\begin{array}{l}\text { Cinzento a } \\
\text { creme claro }\end{array}$ & Regular & $\begin{array}{c}\text { Média, } \\
\text { superficie } \\
\text { lisa e } \\
\text { lustrosa }\end{array}$ & Inodora & Insípida \\
\hline $\begin{array}{l}\text { Cedrorana } \\
\text { (Cedrelinga } \quad \text { catenacformis } \\
\text { Ducke) }\end{array}$ & 0,46 & $\begin{array}{l}\text { Vermelho } \\
\text { róseo }\end{array}$ & Direita & Grosseira & $\begin{array}{c}\text { Desagra- } \\
\text { dável } \\
\text { quando } \\
\text { úmida } \\
\end{array}$ & $\begin{array}{c}\text { Indistin- } \\
\text { to }\end{array}$ \\
\hline $\begin{array}{l}\text { Louro gamela } \\
\text { (Nectandra rubra (Mez.) C.K. } \\
\text { Allen) }\end{array}$ & 0,52 & $\begin{array}{l}\text { Róseo casta- } \\
\text { nho ou par- } \\
\text { do averme- } \\
\text { lhado }\end{array}$ & Regular & $\begin{array}{l}\text { Mediana } \\
\text { a } \\
\text { grosseira }\end{array}$ & $\begin{array}{l}\text { Agradá- } \\
\text { vel, } \\
\text { quando } \\
\text { molhada }\end{array}$ & $\begin{array}{l}\text { Leve- } \\
\text { mente } \\
\text { amargo }\end{array}$ \\
\hline $\begin{array}{l}\text { Breu vermelho } \\
\text { (Protium puncticulatum Macbr.) }\end{array}$ & 0,53 & $\begin{array}{l}\text { Bege rosado } \\
\text { uniforme }\end{array}$ & Regular & Média & Indistinto & $\begin{array}{c}\text { Indistin- } \\
\text { to }\end{array}$ \\
\hline $\begin{array}{l}\text { Cardeiro } \\
\text { (Scleronema } \\
\text { Ducke) }\end{array}$ & 0,59 & $\begin{array}{l}\text { Vermelho } \\
\text { claro lustro- } \\
\text { so }\end{array}$ & Regular & Grosseira & Indistinto & $\begin{array}{c}\text { Indistin- } \\
\text { to }\end{array}$ \\
\hline $\begin{array}{l}\text { Guariúba } \\
\text { (Clarisia racemosa R. et. Pay.) }\end{array}$ & 0,59 & $\begin{array}{l}\text { Variando de } \\
\text { amarelo vi- } \\
\text { vo a casta- } \\
\text { nho amarelo }\end{array}$ & Direita & $\begin{array}{l}\text { Média } \\
\text { uniforme }\end{array}$ & Inodoro & Insípida \\
\hline $\begin{array}{l}\text { Piquiarana } \\
\text { (Cariocar pallidum Aubl.) }\end{array}$ & 0,61 & $\begin{array}{l}\text { Amarelo } \\
\text { pardacento }\end{array}$ & Revessa & Média & Indistinto & $\begin{array}{c}\text { Indistin- } \\
\text { to }\end{array}$ \\
\hline $\begin{array}{l}\text { Cupiúba } \\
\text { (Goupia glabra Aubl.) }\end{array}$ & 0,70 & $\begin{array}{l}\text { Castanho } \\
\text { amarelo a } \\
\text { bege claro/ } \\
\text { rosado }\end{array}$ & $\begin{array}{l}\text { Regular } \\
\quad \mathrm{a} \\
\text { Irregular }\end{array}$ & $\begin{array}{l}\text { Média } \\
\text { a } \\
\text { Grosseira }\end{array}$ & 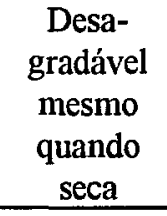 & $\begin{array}{l}\text { Adstrin- } \\
\text { gente }\end{array}$ \\
\hline $\begin{array}{l}\text { Faveira folha-fina } \\
\text { (Piptadenia suaveolens Miq.) }\end{array}$ & 0,72 & $\begin{array}{l}\text { Castanho } \\
\text { cinza escuro } \\
\text { a creme a- } \\
\text { vermelhado } \\
\end{array}$ & Reversa & Grosseira & Inodora & Insipida \\
\hline $\begin{array}{l}\text { Piquiá-marfim } \\
\text { (Aspidosperma obscurinervium } \\
\text { Azambuja.) }\end{array}$ & 0,86 & $\begin{array}{l}\text { Vermelho } \\
\text { escuro/ama- } \\
\text { relo quei- } \\
\text { mado }\end{array}$ & Regular & Média & Indistinto & $\begin{array}{l}\text { Indistin- } \\
\text { to }\end{array}$ \\
\hline
\end{tabular}


Tabela 2. Características das toras ensaiadas.

\begin{tabular}{|c|c|c|c|c|c|c|}
\hline \multirow[t]{2}{*}{ Espécie } & \multirow[t]{2}{*}{$\begin{array}{l}\text { Tora } \\
\mathrm{N}^{\circ}\end{array}$} & \multicolumn{2}{|c|}{$\begin{array}{c}\text { Diâmetro com } \\
\text { casca } \\
(\mathrm{cm})\end{array}$} & \multirow[t]{2}{*}{$\begin{array}{l}\text { Espessura } \\
\text { da casca } \\
\text { (cm) }\end{array}$} & \multirow[t]{2}{*}{$\begin{array}{l}\text { Espessura } \\
\text { do alburno } \\
\quad(\mathrm{cm})\end{array}$} & \multirow{2}{*}{$\begin{array}{l}\text { Excentri- } \\
\text { cidade } \\
\text { da } \\
\text { medula } \\
\text { (cm) }\end{array}$} \\
\hline & & Maior & Menor & & & \\
\hline \multirow{2}{*}{$\begin{array}{l}\text { Ucuúba } \\
\text { branca }\end{array}$} & $85-02$ & 44 & 42 & 1,2 & $\overline{5,0}$ & $\ldots$ \\
\hline & $85-01$ & 50 & 45 & 1,0 & Indistinto & -- \\
\hline \multirow{2}{*}{ Cedrorana } & $362-02$ & 102 & 98 & 1,5 & 1,0 & 10 \\
\hline & $247-02$ & 53 & 51 & 1,0 & 2,0 & 7 \\
\hline \multirow{2}{*}{$\begin{array}{l}\text { Louro } \\
\text { gamela }\end{array}$} & $132-01$ & 44 & 42 & 0,8 & 3,0 & 7 \\
\hline & $130-02$ & 51 & 47 & 1,2 & 5,0 & 5 \\
\hline \multirow{2}{*}{$\begin{array}{l}\text { Breu } \\
\text { vermelho }\end{array}$} & $102-01$ & 44 & 40 & 1,9 & 2,5 & 4 \\
\hline & $101-01$ & 43,5 & 42 & 1,3 & 2,0 & 4 \\
\hline \multirow{2}{*}{ Cardeiro } & $70-01$ & 61,5 & 58,5 & 2,0 & 2,0 & 5 \\
\hline & 73-01 & 61 & 59,5 & 2,5 & 3,0 & -- \\
\hline \multirow{2}{*}{ Guariúba } & $263-01$ & 55 & 53 & 1,0 & 8,0 & 8 \\
\hline & 265-02 & 65 & 60 & 1,3 & 10,0 & 7 \\
\hline \multirow{2}{*}{ Piquiarana } & $617-02$ & 58 & 57 & 2,0 & --- & -- \\
\hline & $631-01$ & 92 & 91 & 1,9 & --- & --- \\
\hline \multirow{2}{*}{ Cupiúba } & $611-01$ & 77 & 75 & 0,8 & 1,0 & -- \\
\hline & $612-01$ & & & 0,4 & 2,0 & 5 \\
\hline \multirow{2}{*}{$\begin{array}{l}\text { Faveira } \\
\text { folha-fina }\end{array}$} & $2-01$ & 48,5 & 47,5 & 1,0 & 1,0 & 5 \\
\hline & $1-02$ & 47,5 & 46 & 1,0 & --- & 6 \\
\hline \multirow{2}{*}{$\begin{array}{l}\text { Piquiá- } \\
\text { marfim }\end{array}$} & $142-01$ & 61 & 60 & 2,2 & 1,0 & -- \\
\hline & $140-02$ & 60 & 59 & 2,1 & 1,0 & -- \\
\hline
\end{tabular}


Tabela 3. Defeitos apresentados pelas toras ensaiadas, com base em GROSSER (1980).

\begin{tabular}{|c|c|c|}
\hline ESPÉCIE & $\begin{array}{c}\text { TORA } \\
\mathrm{N}^{\circ}\end{array}$ & DEFEITO \\
\hline $\begin{array}{l}\text { Ucuúba } \\
\text { branca }\end{array}$ & $\begin{array}{l}85-02 \\
86-01\end{array}$ & $\begin{array}{l}\text { Três nós superficiais; ataques de insetos e fungos } \\
\text { Dois nós superficiais; ataque de insetos e fungos }\end{array}$ \\
\hline Cedrorana & $\begin{array}{l}362-02 \\
247-02\end{array}$ & $\begin{array}{l}\text { Formato cônico; ataque de fungos e insetos; duas rachaduras com } \\
\text { forma estrelada, sendo uma em cada extremo da tora } \\
\text { Duas fendas em forma de arco; rachaduras em anel, sendo uma } \\
\text { em cada extremo da tora }\end{array}$ \\
\hline Louro gamela & $\begin{array}{l}132-01 \\
132-02\end{array}$ & $\begin{array}{l}\text { Um buraco em forma de anel no diâmetro maior; rachadura com } \\
\text { forma estrelada no diâmetro menor } \\
\text { Rachadura em forma de " } \mathrm{T} \text { " no diâmetro maior; rachadura em } \\
\text { forma de "V" no diâmetro menor. Presença de cinco nós } \\
\text { superficiais }\end{array}$ \\
\hline Breu vermelho & $\begin{array}{l}102-01 \\
101-01\end{array}$ & $\begin{array}{l}\text { Duas rachaduras com forma estrelada, sendo uma em cada } \\
\text { extremo da tora } \\
\text { Duas rachaduras com forma estrelada, sendo uma em cada } \\
\text { extremo da tora }\end{array}$ \\
\hline Cardeiro & $\begin{array}{l}70-01 \\
73-02\end{array}$ & $\begin{array}{l}\text { Duas rachaduras na medula, sendo uma cada extremo da tora } \\
\text { Rachaduras estreladas no diâmetro maior; uma rachadura em } \\
\text { forma de "V" no diâmetro menor. Ataques de insetos e manchas }\end{array}$ \\
\hline Guariúba & $\begin{array}{l}263-01 \\
265-02\end{array}$ & $\begin{array}{l}\text { Uma fenda em forma de cruz no diâmetro maior; uma fenda em } \\
\text { forma de arco no diâmetro menor Duas rachaduras em forma de } \\
\text { arco no diâmetro maior e no diâmetro menor. Ataque superficial } \\
\text { de insetos e manchas }\end{array}$ \\
\hline Piquiarana & $\begin{array}{l}617-02 \\
631-01\end{array}$ & $\begin{array}{l}\text { Três nós superficiais; uma fenda em forma de cruz no diâmetro } \\
\text { maior e oito fendas em forma estrelada no diâmetro menor } \\
\text { Dois nós superficiais; uma fenda em forma de "V" em ambos os } \\
\text { diâmetros (maior e menor) }\end{array}$ \\
\hline Cupiúba & $\begin{array}{l}611-01 \\
612-01\end{array}$ & $\begin{array}{l}\text { Uma fenda em forma de cruz no diâmetro maior e outra em forma } \\
\text { de "V" no diâmetro menor } \\
\text { Duas fendas em forma de "Y", sendo uma em cada extremo da } \\
\text { tora }\end{array}$ \\
\hline $\begin{array}{l}\text { Faveira folha- } \\
\text { fina }\end{array}$ & $\begin{array}{l}2-01 \\
1-02\end{array}$ & $\begin{array}{l}\text { Dois nós superficiais; quatro rachaduras com forma estrelada no } \\
\text { diâmetro maior } \\
\text { Duas fendas com forma estrelada, sendo uma no diâmetro maior e } \\
\text { outra no diâmetro menor }\end{array}$ \\
\hline Piquiá-marfim & $\begin{array}{l}142-01 \\
140-02\end{array}$ & $\begin{array}{l}\text { Uma fenda em forma de cruz no diâmetro maior; uma fenda em } \\
\text { forma de T" no diâmetro menor } \\
\text { Uma fenda em forma de cruz no diâmetro maior; uma fenda em } \\
\text { forma de "V" no diâmetro menor }\end{array}$ \\
\hline
\end{tabular}




\subsection{Produção das lâminas.}

As espécies de baixas densidades $\left(0,42\right.$ a $\left.0,53 \mathrm{~g} / \mathrm{cm}^{3}\right)$, não foram submetidas a aquecimento, a excessão da cedrorana, que por ocasião de usa laminação a temperatura ambiente ficou presa entre a faca e a barra de pressão, impedindo seu processamento sem aquecimento prévio.

$\mathrm{O}$ tempo e a temperatura de aquecimento foram baseados em estudos com madeiras tropicais de características similares, realizados por RIVERA (1969), LONDOÑO (1976) e DELGADO (1976).

Assim, levando em consideração basicamente os valores médios dos diâmetros das toras e da densidade básica das espécies, determinou-se tempo e a temperatura de aquecimento para cada espécie (Tabela 4).

Tabela 4. Condições de aquecimento das toras e temperatura no rolo resto

\begin{tabular}{|c|c|c|c|c|c|}
\hline \multirow{2}{*}{ Espécie } & \multirow{2}{*}{$\begin{array}{c}\text { Densidade } \\
\text { básica } \\
\left(\mathrm{g} / \mathrm{m}^{3}\right)\end{array}$} & \multirow{2}{*}{$\begin{array}{l}\text { Diâmetro } \\
\text { médio } \\
\text { das toras } \\
(\mathrm{cm})\end{array}$} & \multirow{2}{*}{$\begin{array}{l}\text { Tempo de } \\
\text { aquecimento } \\
\text { (h) }\end{array}$} & \multicolumn{2}{|c|}{ Temperatura $\left({ }^{\circ} \mathrm{C}\right)$} \\
\hline & & & & Água & Rolo resto $^{(2)}$ \\
\hline Ucuúba branca $^{(1)}$ & 0,42 & $50-48$ & $\overline{-ב-}$ & $-\cdots$ & $\overline{-\cdots}$ \\
\hline Cedrorana & 0,46 & $102-98$ & 48 & 80 & 72 \\
\hline Louro gamela(1) & 0,52 & $51-50$ & $\overline{---}$ & --- & $\begin{array}{l}-- \\
--\end{array}$ \\
\hline Breu vermelho(l) & 0,53 & $45-44$ & -- & -- & $\overline{---}$ \\
\hline Cardeiro & 0,59 & $61-61$ & 40 & 70 & 60 \\
\hline Guariúba & 0,59 & $65-60$ & 48 & $\overline{80}$ & 72 \\
\hline Piquiarana & 0,61 & $92-91$ & 48 & 90 & 76 \\
\hline Cupiúba & 0,70 & $80-78$ & 48 & 90 & 84 \\
\hline $\begin{array}{l}\text { Faveira folha- } \\
\text { fina }\end{array}$ & 0,72 & $50-47$ & 52 & 90 & 82 \\
\hline Piquiá-marfim & 0,86 & $62-61$ & 48 & 90 & 82 \\
\hline
\end{tabular}

(1) Espécies não submetidas a aquecimento, isto é, laminadas à temperatura ambiente.

(2) A temperatura no rolo resto foi medida imediatamente após a laminação. 
Após o aquecimento as toras foram retiradas do tanque, destopadas $15 \mathrm{~cm}$ em cada extremo, e descascadas manualmente (Durante esta operação foram feitas observações quanto a facilidade de descascamento e quanto ao efeito do aquecimento sobre as rachaduras nos extremos das toras).

Para a laminação foi utilizado um torno desenrolador FEZER modelo 15 PA 18, movido a eletricidade, equipado com uma barra de pressão fixa e um dispositivo que corrige automaticamente o ângulo da faca durante o transcorrer do corte. A regulagem do torno, descrita na Tabela 5, foi constante para todas as espécies.

Tabela 5. Regulagens do torno e espessura nominal visada.

\begin{tabular}{||c|c|c|c|c||}
\hline $\begin{array}{c}\text { Angulo } \\
\text { da } \\
\text { faca }\end{array}$ & $\begin{array}{c}\text { Angulo de } \\
\text { afiação } \\
\text { da faca }\end{array}$ & $\begin{array}{c}\text { Abertura } \\
\text { horizontal } \\
\text { da barra de pressão } \\
(\mathrm{mm})\end{array}$ & $\begin{array}{c}\text { Abertura vertical } \\
\text { da barra de pressão } \\
(\mathrm{mm})\end{array}$ & $\begin{array}{c}\text { Espessura } \\
\text { nominal } \\
(\mathrm{mm})\end{array}$ \\
\hline $91^{\circ} 00^{\prime}$ & $20^{\circ} 00^{\prime}$ & 1,44 & 0,36 & 1,6 \\
\hline
\end{tabular}

Depois de centralizada a tora no torno e feito o desbaste, foi medida a circunferência no centro e posicionou-se os canivetes a $10 \mathrm{~cm}$ de cada extremo, de forma que as lâminas produzidas tivessem um largura de $1,5 \mathrm{~m}$.

Durante a laminação registrou-se a facilidade de corte e os defeitos internos apresentados pela madeira. Ao termino do corte, conferiu-se novamente as aberturas horizontal e vertical, com a finalidade de detectar distorções e mediuse a temperatura final no centro do rolo resto.

A lâmina contínua foi guilhotinada obtendo-se lâminas individuais com $1,0 \mathrm{~m}$ de comprimento. Durante a guilhotinagem, foram eliminados todos os defeitos graves que a madeira apresentava, tais como, rachaduras muito abertas, 
grandes nós soltos, buracos e outros defeitos de origens distintas.

Para determinação do teor de umidade foram separadas ao acaso 3 lâminas de $1,5 \mathrm{~m} \times 1,0 \mathrm{~m}$ de cada tora, e de cada lâmina retirou-se uma amostra de $15 \mathrm{~cm}$ de largura por $50 \mathrm{~cm}$ de comprimento. $\mathrm{O}$ teor de umidade foi determinado pelo método de secagem a $103( \pm 2)^{\circ} \mathrm{C}$.

A secagem das lâminas foi realizada em secador semi-industrial marca KELLER, com comprimento de 4,0m provido de uma plataforma de transporte. A temperatura de secagem foi de $160^{\circ} \mathrm{C}$ e a velocidade de deslocamento das lâminas foi de $\mathrm{lm} / \mathrm{min}$, iguais para todas as espécies.

Para a quantificação da contração tangencial foram separadas aleatoriamente 3 lâminas de cada tora, medindo-se o seu comprimento (direção perpendicular as fibras) nas condições úmida e seca (ao sair do secador).

Depois de secas, as lâminas foram armazenadas durante 30 dias em uma câmara de aclimatação com uma temperatura de $20( \pm 3)^{\circ} \mathrm{C}$ e umidade relativa de $65( \pm 1) \%$, para que obtivesse massa e umidade constante, conforme recomendações da norma ASTM D - 85/72 (ASTM, 1976).

\subsection{Avaliação da qualidade das lâminas.}

De cada espécie em estudo foram separadas, inteiramente ao acaso, 11 lâminas de 1,5m x 1,0m e de cada umá destas lâminas, após a secagem, foi retirada aleatoriamente, uma amostra de $20 \mathrm{~cm} \times 20 \mathrm{~cm}$, destinada aos testes de rugosidade e uniformidade de espessura.

A espessura das lâminas foi medida com um micrômetro digital Mitutoyo, com precisão de $0,01 \mathrm{~mm}$. Para qualificar a uniformidade de espessura foram feitas 5 medições em cada uma das amostras, sendo uma medição em cada 
canto e uma medição no centro da lâmina, representando um total de 55 medições por espécie.

Após a realização destes testes, as amostras foram cortadas visando obter corpos de prova utilizados nos ensaios de tração normal e do número $\mathrm{e}$ profundidade das fendas de laminação, conforme esquema mostrado na Figura 4.

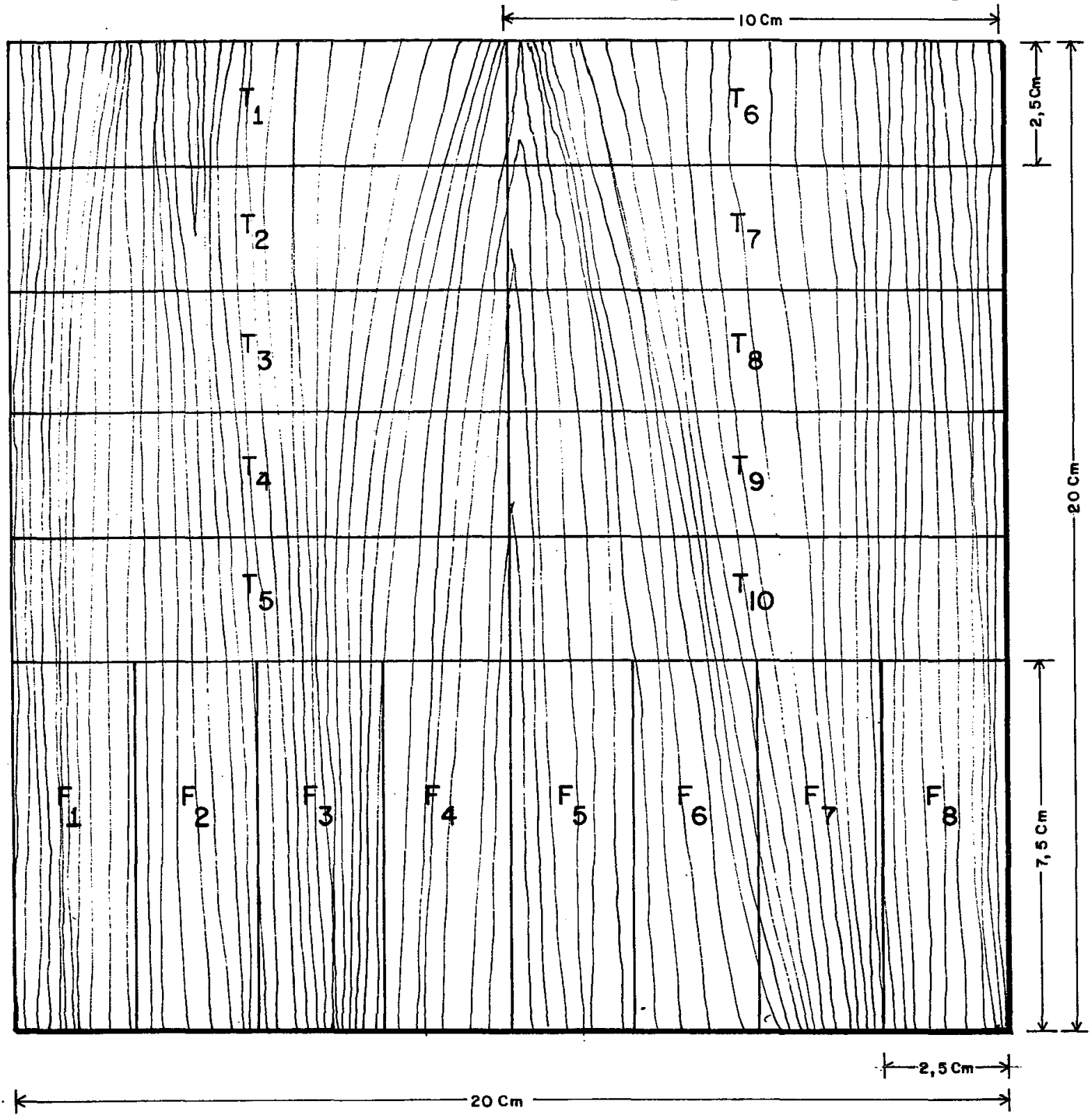

Figura 4. Representação esquemática dos corpos de provas para teste de tração normal $(\mathrm{T})$ e do número e profundidade das fendas de laminação $(\mathrm{F})$. 
A avaliação da rugosidade foi feita de maneira subjetiva por dois especialistas da área com base em LONDOÑO (1970), utilizando-se o seguinte procedimento:

a) foram selecionadas, comparando a rugosidade de todas as 110 amostras, a lâmina mais lisa, a mais rugosa e duas lâminas com rugosidades intermediárias, classificadas como lisa (1), moderadamente rugosa (2), rugosa (3) e muito rugosa (4);

b) a classificação das demais lâminas foi feita comparando-se de maneira subjetiva, sua rugosidade com as 4 amostras padrões.

O ensaio de resistência das lâminas à tração normal foi realizado pelo método todo desenvolvido por KIVIMAA (1956). O objetivo deste ensaio é avaliar o efeito das condições de laminação (pressão da barra de compressão) na resistência das lâminas.

Os corpos de prova de $2,5 \mathrm{~cm} \mathrm{x} 10 \mathrm{~cm}$ (dimensão menor paralela as fibras, Figura 4), foram ensaiadas em máquina universal de testes marca INSTRON, com capacidade de carga de $5 \mathrm{MPa}$. A velocidade de aplicação de carga foi de $0,5 \mathrm{~cm} / \mathrm{min}$, e a distância entre as garras foi de $5 \mathrm{~cm}$.

$\mathrm{O}$ número e a profundidade das fendas de laminação foram quantificados segundo o método desenvolvido por LIMBACH (1946). O método consiste em vedar com parafina o extremo da lâmina que contem as fendas, para em seguida impregna-lo com uma substância corante, de forma que se obtenha uma superfície contrastante entre as fendas e a madeira.

O objetivo deste ensaio é quantificar as fendas de laminação, as quais, por sua vez, são recorrentes das condições de corte (principalmente das regulagens do torno desenrolador).

Com o auxílio de uma lupa, provida de escala milimétrica, mede- 
se a profundidade em relação a espessura real da lâmina e conta-se o número de fendas por centímetro, conforme é mostrado na Figura 5.
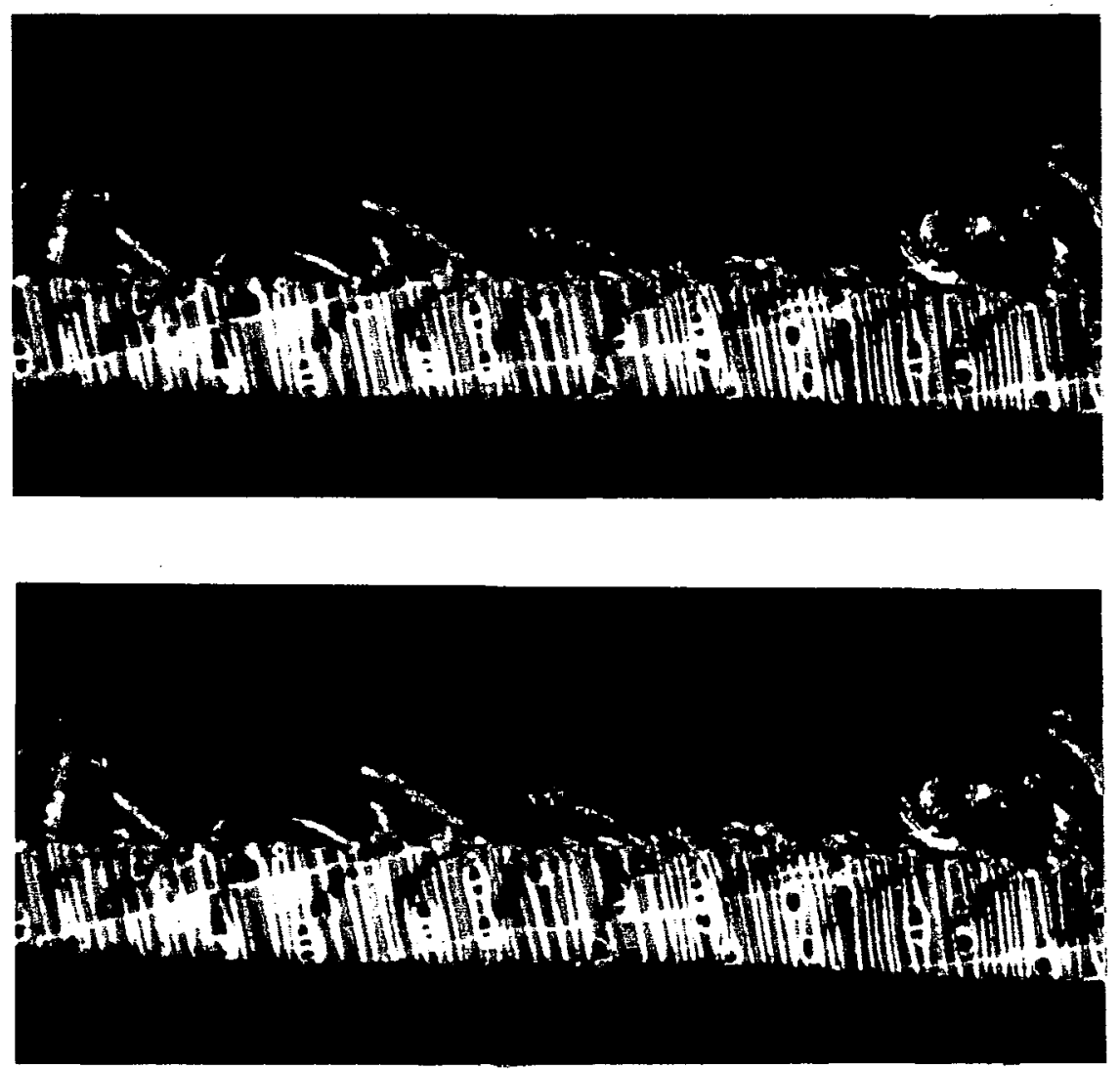

Figura 5. Número e profundidade das fendas de lâminação.

3.4. Manufatura e qualificação do compensado.

Para a manufatura dos compensados foram aleatoriamente coletadas, de cada espécie, 9 lâminas, recortadas de forma que ficassem com comprimento e largura iguais $(1,0 \mathrm{~m} \times 1,0 \mathrm{~m})$ e utilizadas na confecção de 3 
painéis tri-laminados.

O teor de umidade das lâminas antes de serem coladas foi determinado com um medidor elétrico, apresentando valores variando de 8,6\% a $9,2 \%$.

$\mathrm{O}$ adesivo utilizado foi uma resina de fenolformaldeído, com formulação e demais parâmetros de colagem seguindo as recomendações do fabricante, conforme Tabelas 6 e 7 .

Após a manufatura, os painéis foram armazenados por 30 dias em uma câmara de aclimatação [temperatura de $20( \pm 3)^{\circ} \mathrm{C}$ e umidade relativa de $65( \pm 1) \%$ ], para posterior obtenção dos corpos de prova destinados aos ensaios de resistência ao cisalhamento e análise de falha na madeira.

Tabela 6. Formulação do adesivo utilizado.

\begin{tabular}{||l|c|c||}
\hline $\begin{array}{c}\text { COMPONENTES DO } \\
\text { ADESIVO }\end{array}$ & $\begin{array}{c}\text { PARTES } \\
\text { (em massa) }\end{array}$ & $\begin{array}{c}\% \\
\text { (em massa) }\end{array}$ \\
\hline $\begin{array}{l}\text { Resina fenol-formaldeído } \\
\text { (CASCOPHEN IV-80) }\end{array}$ & 100 & 80,0 \\
\hline Albex - 3 (Pó de casca de nozes) & 10 & 8,0 \\
\hline Albex - 1 (Farinha de trigo) & 5 & 4,0 \\
\hline Água & 10 & 8,0 \\
\hline
\end{tabular}


Tabela 7. Condições de montagem e prensagem.

\begin{tabular}{|c|c||}
\hline GRAMATURA & \\
linha dupla de cola & $320 \mathrm{~g} / \mathrm{m}^{2}$ \\
\hline CONDIÇÕES DE MONTAGEM & \\
Aberto (formação do painel) & $3 \mathrm{~min}$ \\
Fechado (painel formado) & $45 \mathrm{~min}$ \\
\hline CONDIÇÕES DE PRENSGEM & \\
tempo & $1 \mathrm{~min} / \mathrm{mm}$ \\
temperatura & $130^{\circ} \mathrm{C}$ \\
pressão específica & $10 \mathrm{kgf} / \mathrm{cm}^{2}$ \\
\hline
\end{tabular}

De cada painel foram retirados 36 corpos de prova (segundo esquema mostrado na Figura 6), de acordo com a norma PS 51-71 (NBS, 1972). Deste total, 18 corpos de prova foram testados em condições ambientais (condição seca), e os outros 18 após dois ciclos de envelhecimento rápido (condição úmida), que consiste em $4 \mathrm{~h}$ de cozimento em água fervente seguido de uma secagem de $20 \mathrm{~h}$ em estufa a $65( \pm 3)^{\circ} \mathrm{C}$ por ciclo.

A qualificação do compensado teve como base os valores médios da resistência ao cisalhamento e a porcentagem de falha na madeira, a qual foi quantificada eletronicamente, através de um micro-videomat acoplado a um micro computador. O método seguido para a realização deste ensaio foi o desenvolvido por VETTER \& SILVA (1988).

No total foram testados, por espécie, 54 corpos de prova na condição seca e 54 corpos de prova na condição úmida. 

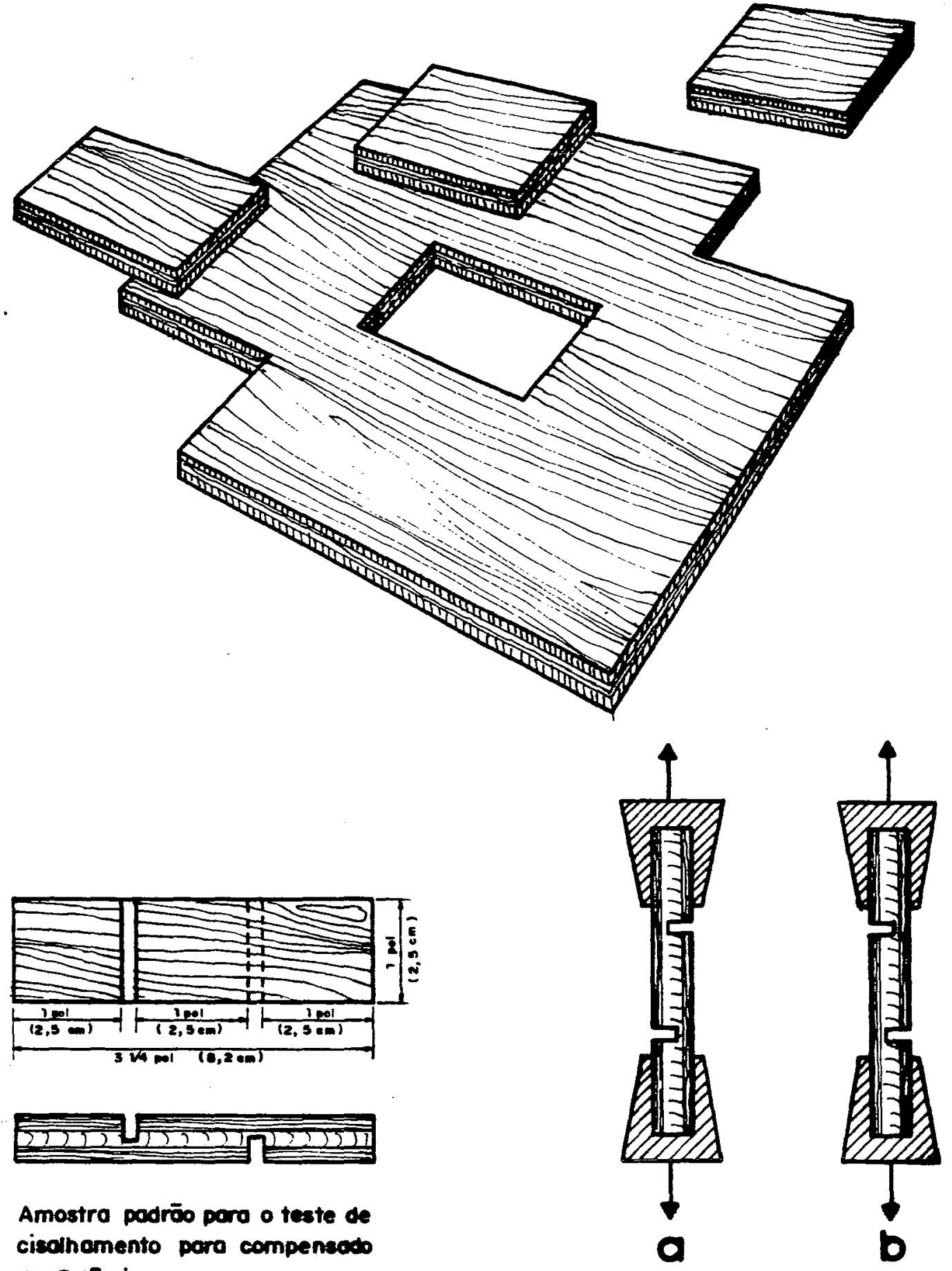

Amostra padrōo pora o teste de cisalhomento paro compeneato de 3 lâminas.

Ikustraçāo do teste de cisalhamento sob trogōo mostranto: a) A tropio forçando o fechamento das fendos de raminacōo. b) A trogōo forcando uma abertura nas fendas.

Figura 6. Esquema de amostragem e execução do ensaio de cisalhamento na linha de cola. 


\section{RESULTADOS E DISCUSSÃO.}

\subsection{Laminação e secagem.}

O comportamento das espécies durante os processos de laminação e de secagem das lâminas é sumarizado na Tabela 8.

Tabela 8. Resumo do comportamento das espécies durante os processos de laminação e secagem.

\begin{tabular}{|l|l|l|}
\hline \multicolumn{1}{|c|}{ Espécie } & \multicolumn{1}{|c|}{ Lâminação } & \multicolumn{1}{c|}{ Secagem } \\
\hline Ucuúba branca & Normal & Normal \\
\hline Cedrorana & Normal & Normal \\
\hline Louro gamela & Normal & Normal \\
\hline Breu vermelho & Normal & Normal \\
\hline Cardeiro & $\begin{array}{l}\text { Normal } \\
\text { Canais secretores }\end{array}$ & Normal \\
\hline Guariúba & Normal & Ondulações superficiais \\
\hline Piquiarana & $\begin{array}{l}\text { Desgastes da faca (abrasão } \\
\text { e quebra) } \\
\text { Vibrações no conjunto } \\
\text { cortante }\end{array}$ & Ondulações superficiais \\
\hline Cupiúba & Normal & Normal \\
\hline Faveira folha-fina & $\begin{array}{l}\text { Desgastes da faca (abrasão } \\
\text { e quebra) } \\
\text { Vibrações no conjunto } \\
\text { cortante }\end{array}$ & Ondulações superficiais \\
\hline Piquiá-marfim & $\begin{array}{l}\text { Desgastes da faca (Abrasão } \\
\text { e quebra) } \\
\text { Vibrações no conjunto } \\
\text { cortante }\end{array}$ & $\begin{array}{l}\text { Fibras superficiais soltas, } \\
\text { aumento na largura das } \\
\text { fendas de topo }\end{array}$ \\
\hline
\end{tabular}


Foram observados problemas de laminação das espécies Piquiámarfim, Piquiarana e Faveira folha-fina. A principal dificuldade foi o desgaste sofrido pela faca, verificando-se tanto a ocorrência de pequenas rupturas e deformação do aço como a perda do fio da faca, que é característica da abrasão.

Segundo LUTZ (1974), rupturas e deformações do aço ocorrem quando a faca corta nós duros, não suficientemente aquecidos, ou formações petrificadas. Já a abrasão acentuada ocorre quando a madeira contem $1 \%$ ou mais de sílica ou carbonato de cálcio na sua composição química. Nós foi um dos defeitos observados nas espécies piquiarana e faveira folha-fina, conforme é demonstrado na Tabela 3 .

MAINIERI \& CHIMELO (1989), descrevem o gênero Aspidosperma como possuidores de cristais romboidais em células subdivididas com 3 a 8 cristais por série. FEDALTO et ali (1989) encontraram cristais de oxalato de cálcio; rombodais em séries hemi e holocristalíferas, em células septadas do parenquima axial, mais comumente no limite com as fibras, na madeira da Faveira folha-fina .

Durante a laminação dessas espécies observou-se também vibração excessiva no conjunto cortante, com um som estridente quando do contato da faca com a madeira. Para FEIHL \& GODIN (1970), este problema ocorre principalmente em função do ângulo da faca ser muito grande. Quando isto ocorre, o torno começa a produzir lâminas muito rugosa. Neste estudo este fato pode ser comprovado, uma vez que as referidas espécies foram as que apresentaram as lâminas mais rugosas, como pode ser observado na Tabela 9.

No corte da espécie Cardeiro observou-se a presença de canais secretores contínuos, que algumas vezes provocaram o rompimento da lâmina. Contudo, esse problema é decorrente da estrutura anatômica da madeira, sem 
prejudicar o processo de laminação ou a qualidade das lâminas.

Tabela 9. Avaliação da rugosidade das lâminas (teor de umidade: mín. $=6,60 \%$; máx. $=9,06 \%$; média $=7,83 \%$ ).

\begin{tabular}{|c|c|c|c|c|c|}
\hline \multirow{2}{*}{ Espécie } & \multirow{2}{*}{$\begin{array}{c}\text { Densidade } \\
\text { básica } \\
\left(\mathrm{g} / \mathrm{cm}^{3}\right) \\
\end{array}$} & \multicolumn{4}{|c|}{ Classe de Rugosidade } \\
\hline & & $\mathrm{I}$ & II & III & IV \\
\hline Ucuúba branca & 0,42 & --.- & 8 & 3 & $\overline{-1--}$ \\
\hline Cedrorana & 0,46 & --- & 4 & 7 & -- \\
\hline Louro gamela & 0,52 & $-\cdots$ & 2 & 9 & -- \\
\hline Breu vermelho & 0,53 & 5 & 6 & $-\cdots$ & -- \\
\hline Cardeiro & 0,59 & $-\cdots$ & 6 & 5 & -- \\
\hline Guariúba & 0,59 & --- & 2 & 9 & --- \\
\hline Piquiarana & 0,61 & --- & --- & 5 & 6 \\
\hline Cupiúba & 0,70 & $\cdots$ & $-\cdots$ & 11 & +-- \\
\hline Faveira folha-fina & 0,72 & -- & $-\cdots$ & 6 & 5 \\
\hline Piquiá-marfim & 0,86 & -- & -- & -- & 11 \\
\hline
\end{tabular}

O embobinamento em todos os casos foi realizado continuamente, sendo a manta facilmente enrolada nos carretéis. As rachaduras de topo, pouco existentes em algumas espécies, dobraram-se sem problemas.

$\mathrm{O}$ teor de umidade inicial entre as espécies variou de $84,3 \%$ a $30,5 \%$, e o teor de umidade final ficou compreendido entre um máximo de $10 \%$ e um mínimo de 6\%. Estes resultados são apresentados na Tabela 10.

A contração tangencial das lâminas ocorrida durante a secagem esteve compreendida entre um máximo de $9 \%$ para a espécie Piquiarana, e um mínimo de 5\% para a espécie Guariúba. Estes resultados estão expressos na Tabela 10. 
Tabela 10. Medidas dos teores de umidade inicial, final e retração tangencial das lâminas (entre parenteses é apresentado o valor de desvio padrão).

\begin{tabular}{|l||c||c||c||c||}
\hline \multicolumn{1}{|c||}{ Espécie } & $\begin{array}{c}\text { Número de } \\
\text { Amostras }\end{array}$ & $\begin{array}{c}\text { Umidade } \\
\text { Inicial } \\
(\%)\end{array}$ & $\begin{array}{c}\text { Umidade } \\
\text { Final } \\
(\%)\end{array}$ & $\begin{array}{c}\text { Contração } \\
\text { Tangencial } \\
(\%)\end{array}$ \\
\hline Ucuúba branca & 6 & $84,30(3,9)$ & $7,0(0,7)$ & $5,0(0,5)$ \\
\hline Cedrorana & 6 & $60,60(3,5)$ & $8,0(0,4)$ & $7,0(0,7)$ \\
\hline Louro gamela & 6 & $63,23(1,4)$ & $10,0(0,7)$ & $6,0(0,3)$ \\
\hline Breu vermelho & 6 & $46,30(2,9)$ & $8,0(0,4)$ & $6,0(0,3)$ \\
\hline Cardeiro & 6 & $54,30(4,1)$ & $5,0(0,7)$ & $8,0(0,8)$ \\
\hline Guariúba & 6 & $45,20(2,5)$ & $10,0(1,0)$ & $5,0(0,5)$ \\
\hline Piquiarana & 6 & $56,26(1,0)$ & $6,0(0,1)$ & $9,0(0,4)$ \\
\hline Cupiúba & 6 & $47,02(0,2)$ & $6,0(0,4)$ & $7,0(0,03)$ \\
\hline Faveira folha-fina & 6 & $30,50(3,9)$ & $6,0(0,3)$ & $6,0(0,3)$ \\
\hline Piquiá-marfim & 6 & $46,00(2,7)$ & $6,0(0,5)$ & $6,0(0,5)$ \\
\hline \hline
\end{tabular}

Não foram verificados problemas durante a secagem das espécie Cupiúba, Cedrorana, Breu vermelho, Cardeiro, Louro gamela e Ucuúba branca. Porem, as. lâminas das espécies Piquiarana, Guariúba e Faveira folha-fina apresentaram ondulações na superfície, sendo este defeito mais acentuado nas duas primeiras espécies.

Esta deformidade pode ter como causa a estrutura vegetativa, característica de cada espécie. Já as lâminas da espécie Piquiá-marfim, apresentaram fibras soltas sobre a superfície e as rachaduras já existentes antes da secagem incrementaram-se em largura mas não em comprimento. Todavia, as lâminas resultaram planas e compactas.

Para FEIHL \& GODIN (1970), fibras soltas sobre a superficie das lâminas é devido a abertura vertical estar muito pequena ou a barra de compressão estar com um ângulo muito agúdo, ou ainda, o ângulo da faca estar muito pequeno. 


\subsection{Qualidade das lâminas.}

A rugosidade das lâminas variou entre as espécies, segundo a classificação estabelecida, desde lisa a muito rugosa. Em sua maioria, as lâminas foram classificadas como moderadamente rugosa e rugosa.

Examinando a Tabela 9, observa-se que as lâminas das espécies Piquiá-marfim, Piquiarana e Faveira folha-fina apresentam as lâminas mais rugosas, enquanto que o Breu vermelho e a Ucuúba branca se destacam com as lâminas mais lisas. Esses resultados mostram uma tendência de que com o aumento da densidade básica aumenta também a rugosidade das lâminas, como é mostrado na Figura 7.

Para avaliar a uniformidade de espessura das lâminas foram feitas ao todo 550 medições, de acordo com a metodologia descrita no item 3.3. Os resultados obtidos estão resumidos na Tabela 11.

Comparando a densidade básica das espécies com as espessuras das lâminas, observa-se que aquelas de maior densidade apresentam espessura superior as de menor densidade, conforme pode ser observado na Figura 8.

Deve-se ressaltar que o valor da densidade básica utilizado no cálculo das regressões em função da rugosidade e da espessura, é a média determinada para a espécie. 


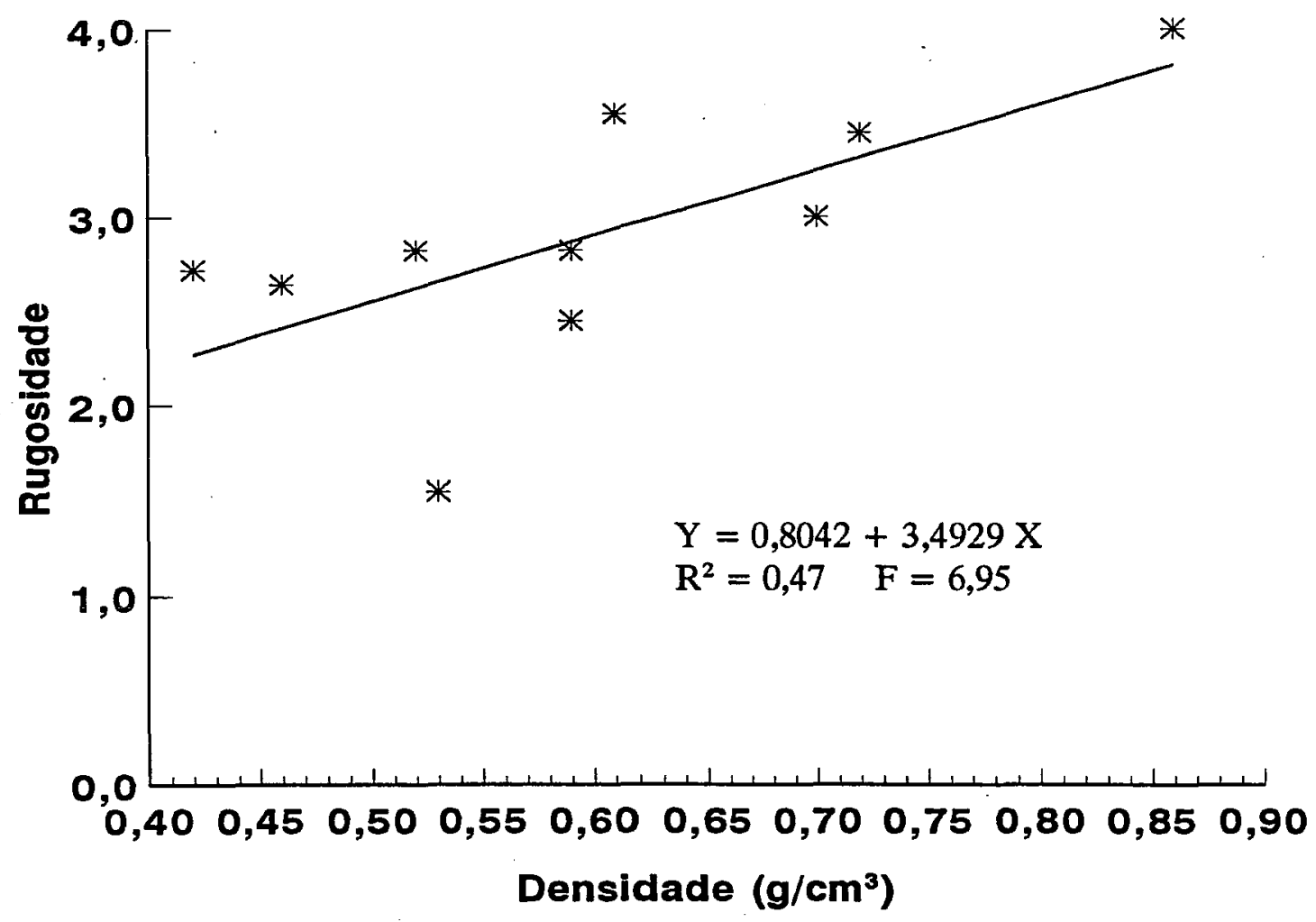

Figura 7. Representação gráfica da correlação entre a rugosidade das lâminas e a densidade básica, para as espécies estudadas.

Tabela 11. Espessura média das lâminas secas (teor de umidade: máximo = 10,10\%; mínimo $=5,79 ;$ média $=7,94 \%$ ).

\begin{tabular}{||l|c|c|c||}
\hline \multicolumn{1}{|c|}{ Espécie } & $\begin{array}{c}\text { Número de } \\
\text { Medições }\end{array}$ & $\begin{array}{c}\text { Espessura Média } \\
\text { das Lâminas (mm) }\end{array}$ & Desvio Padrão \\
\hline \hline Ucuúba branca & 55 & 1,54 & 0,04 \\
\hline Cedrorana & 55 & 1,58 & 0,01 \\
\hline Louro gamela & 55 & 1,56 & 0,02 \\
\hline Breu vermelho & 55 & 1,54 & 0,02 \\
\hline Cardeiro & 55 & 1,60 & 0,02 \\
\hline Guariúba & 55 & 1,62 & 0,02 \\
\hline Piquiarana & 55 & 1,60 & 0,03 \\
\hline Cupiúba & 55 & 1,63 & 0,03 \\
\hline Faveira folha-fina & 55 & 1,62 & 0,03 \\
\hline Piquiá-marfim & 55 & 1,66 & 0,05 \\
\hline
\end{tabular}




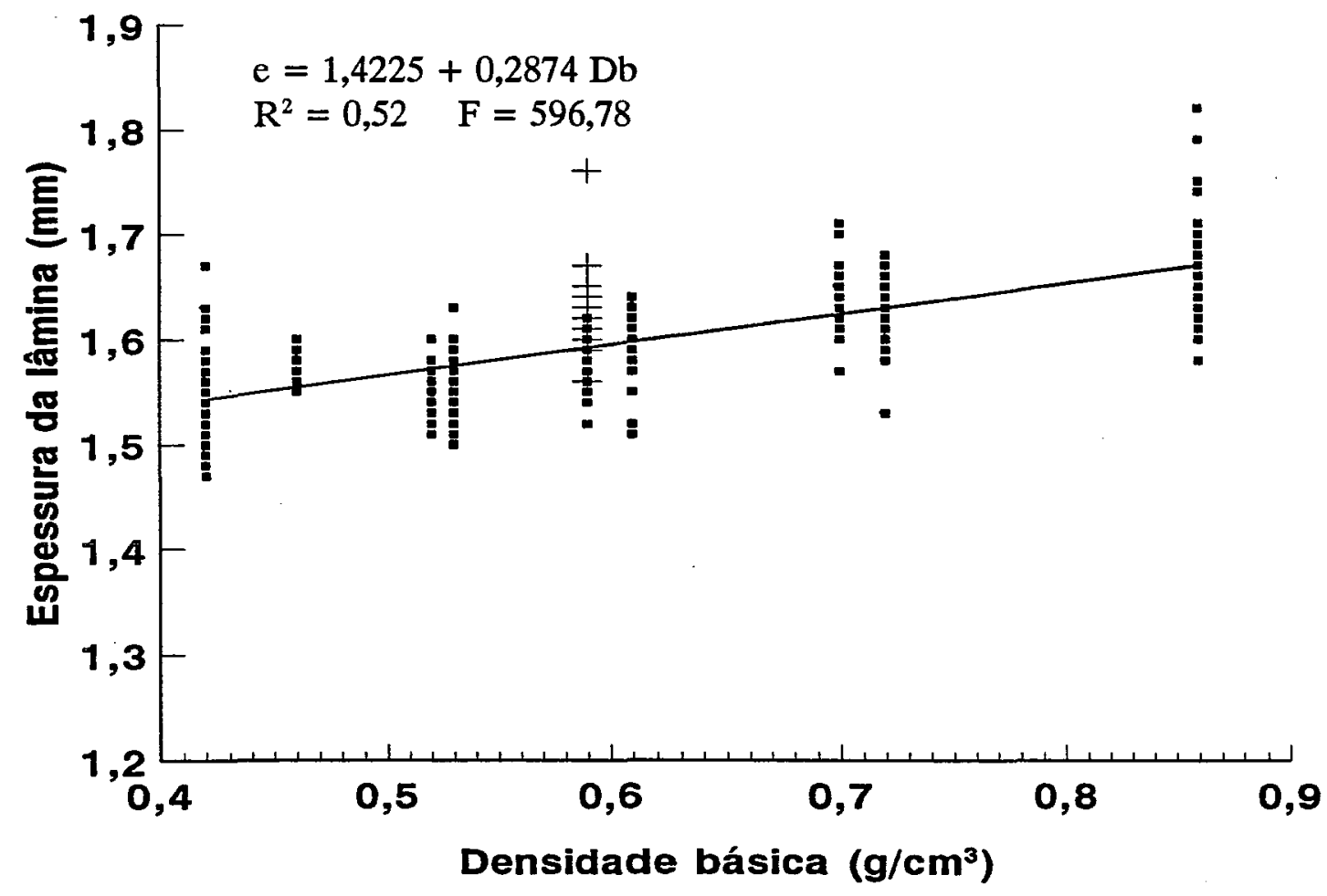

Figura 8. Representação gráfica da correlação entre a espessura real das lâminas e a densidade básica, para as espécies estudadas.

Esse comportamento pode ser melhor avaliado na Figura 9, onde é observado que, para uma mesma regulagem de torno, as espécies menos densas apresentam uma tendência de serem mais comprimidas durante o corte, resultando em lâminas cuja espessura final é inferior a espessura nominal desejada. 


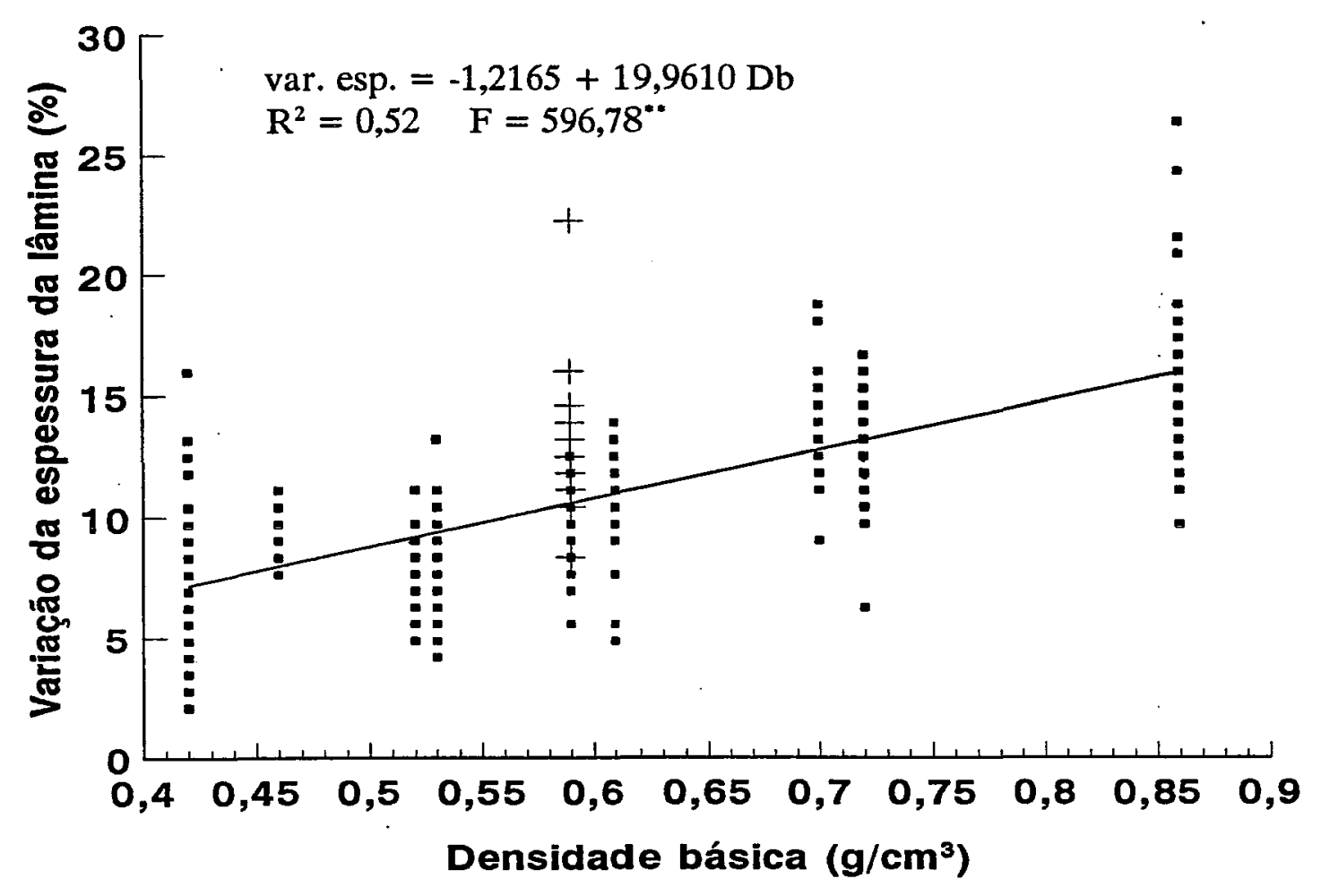

Figura 9. Representação gráfica da variação na espessura das lâminas em função da densidade básica.

Os resultados obtidos no ensaio de resistência da lâmina à tração normal são apresentados na Tabelas 12 e na Figura 10. Foram ensaiados 971 corpos de prova, com a umidade variando de 5,79\% a 10,10\% (média de $8,63 \%$ ). A tensão de ruptura variou de $1,7 \mathrm{MPa}$ (Faveira folha-fina) a $0,7 \mathrm{MPa}$ (Piquiarana). 
Tabela 12. Valores da tensão de ruptura das lâminas a tração normal.

\begin{tabular}{||l|c|c|c||}
\hline \multicolumn{1}{|c|}{ Espécie } & $\begin{array}{c}\text { No. Corpos } \\
\text { de Prova }\end{array}$ & $\begin{array}{c}\text { Tensão Normal } \\
(\mathrm{MPa})\end{array}$ & Desvio Padrão \\
\hline Ucuúba branca & 100 & 0,92 & 0,23 \\
\hline Cedroarana & 82 & 1,02 & 0,45 \\
\hline Louro gamela & 100 & 0,73 & 0,14 \\
\hline Breu vermelho & 100 & 1,12 & 0,38 \\
\hline Cardeiro & 100 & 0,86 & 0,20 \\
\hline Guariúba & 100 & 1,21 & 0,27 \\
\hline Piquiarana & 100 & 0,98 & 0,27 \\
\hline Cupiúba & 92 & 0,73 & 0,21 \\
\hline Faveira folha-fina & 100 & 1,71 & 0,61 \\
\hline Piquiá-marfim & 97 & 1,30 & 0,38 \\
\hline
\end{tabular}

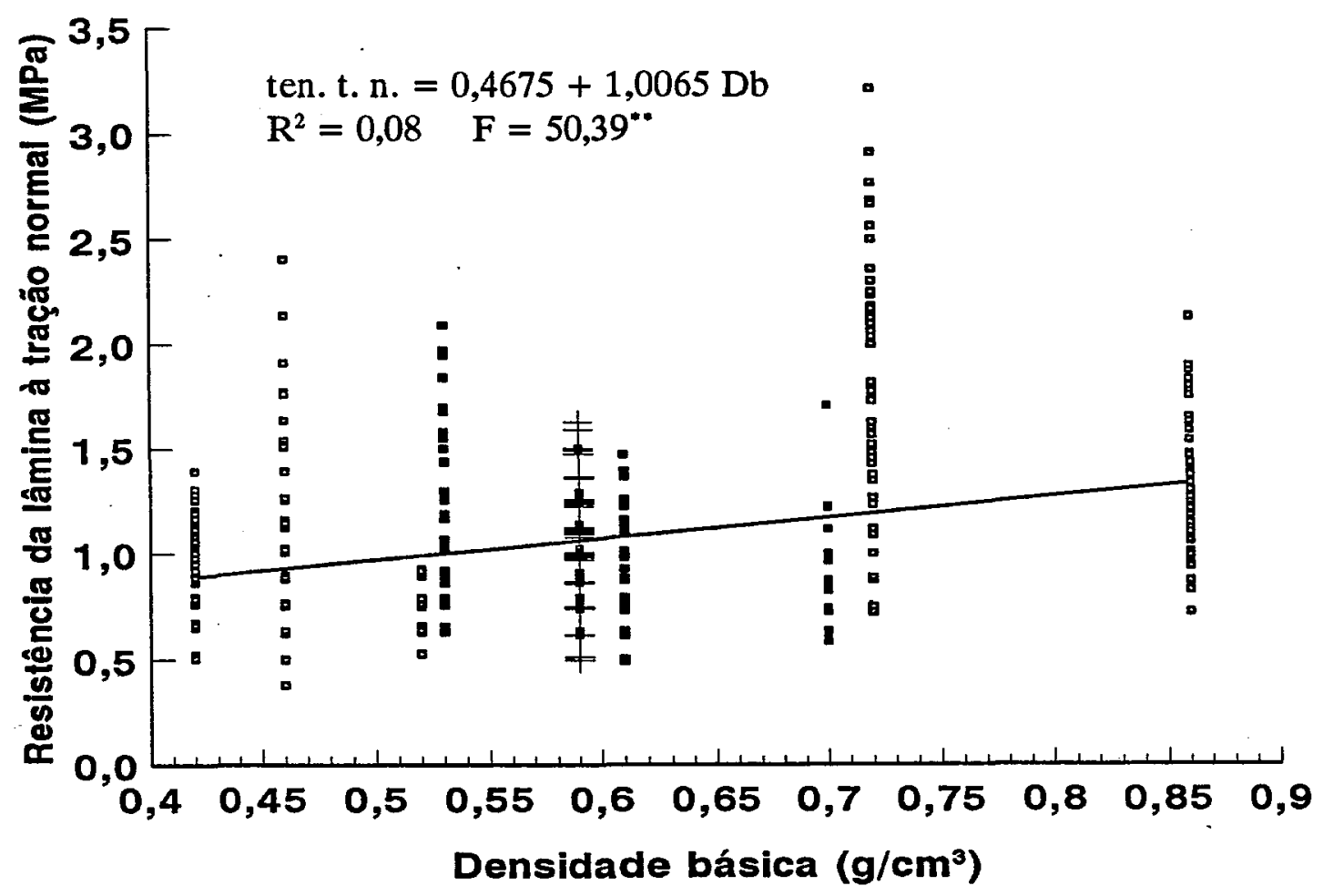

Figura 10. Representação gráfica da correlação entre a tensão de ruptura das lâminas a tração normal e a densidade básica. 
Os resulados da avaliação do número e da profundidade das fendas de laminação, medidos em 680 corpos de prova, estão contidos na Tabela 13. O número de fendas por centímetro linear variou entre 6 a 8 . A profundidade das fendas de laminação na maioria das espécies foi acentuada, com uma média de 90\% para a espécie Cupiúba. A espécie Breu vermelho foi a que apresentou o menor índice, com $42 \%$ de profundidade média nas lâminas.

Tabela 13. Resultados da avaliação do número e profundidade das fendas de laminação.

\begin{tabular}{||l|c|c|c|c|c||}
\hline \multicolumn{1}{|c|}{ Espécie } & $\begin{array}{c}\text { Número } \\
\text { de } \\
\text { Amostras }\end{array}$ & $\begin{array}{c}\text { Número } \\
\text { de } \\
\text { Fendas } \\
(\mathrm{N} / \mathrm{cm})\end{array}$ & $\begin{array}{c}\text { Desvio } \\
\text { Padrão }\end{array}$ & $\begin{array}{c}\text { Profundidade } \\
\text { das Fendas } \\
(\%)\end{array}$ & $\begin{array}{c}\text { Desvio } \\
\text { Padrão }\end{array}$ \\
\hline \hline Ucuúba branca & 67 & 8 & 1,50 & 62 & 3,80 \\
\hline Cedrorana & 67 & 7 & 1,20 & 70 & 5,00 \\
\hline Louro gamela & 66 & 6 & 3,00 & 67 & 21,60 \\
\hline Breu vermelho & 67 & 8 & 1,80 & 42 & 10,40 \\
\hline Cardeiro & 67 & 6 & 1,20 & 56 & 6,70 \\
\hline Guariúba & 67 & 7 & 1,10 & 80 & 3,00 \\
\hline Piquiarana & 72 & 6 & 1,54 & 83 & 12,00 \\
\hline Cupiúba & 63 & 7 & 1,76 & 90 & 16,70 \\
\hline $\begin{array}{l}\text { Faveira folha- } \\
\text { fina }\end{array}$ & 77 & 8 & 2,05 & 52 & 18,10 \\
\hline Piquiá-marfim & 67 & 6 & 0,95 & 80 & 9,66 \\
\hline
\end{tabular}

Nos resultados da Tabela 12 e Figura 10 nota-se uma tendência das lâminas obtidas das espécies mais densas apresentarem maiores valores da tensão de ruptura.

Em tentativa de isolar o efeito das fendas de laminação no ensaio de resistência a tração normal, parte dos resultados da Tabela 12 foram 
recalculados, descontando-se da espessura da lâmina na profundidade média da fenda de laminação.

Esse procedimento reduz (para efeitos de cálculo) a área submetida a tração, aproximando o resultado experimental da condição real de ensaio.

Esses resultados aqui denominados de resistência corrigida, são apresentados na Tabela 14 e Figura 11.

Tabela 14. Valores de resistência corrigida para a tensão normal.

\begin{tabular}{||l|c|c|c|}
\hline \multicolumn{1}{|c|}{ Espécie } & $\begin{array}{c}\mathrm{N}^{\circ} \text { Corpos } \\
\text { de Prova }\end{array}$ & $\begin{array}{c}\text { Tensão Ruptura } \\
(\mathrm{MPa})\end{array}$ & Desvio Padrão \\
\hline \hline Ucuúba branca & 100 & 3,20 & 2,00 \\
\hline Cedrorana & 82 & 7,00 & 3,15 \\
\hline Louro gamela & 100 & 2,20 & 6,00 \\
\hline Breu vermelho & 100 & 1,90 & 4,80 \\
\hline Cardeiro & 100 & 2,10 & 6,35 \\
\hline Guariúba & 100 & 4,20 & 2,55 \\
\hline Piquiarana & 100 & 4,30 & 8,00 \\
\hline Cupiúba & 92 & 9,20 & 4,45 \\
\hline Faveira folha-fina & 100 & 3,60 & 1,35 \\
\hline Piquiá-marfim & 97 & 6,50 & 5,11 \\
\hline
\end{tabular}

Observa-se que premanece, a tendência das lâminas de espécies mais densas mostrarem-se mais resistentes ao esforço de tração, mas com um coeficiente de determinação $\left(\mathrm{R}^{2}\right)$ ainda baixo.

Considerando-se que as espécies mais densas tendem a apresentar fendas de laminação mais profundas, era de se esperar que os valores da resistência corrigida fossem dependentes da densidade básica, o que não foi demonstrado pela análise de regressão. 


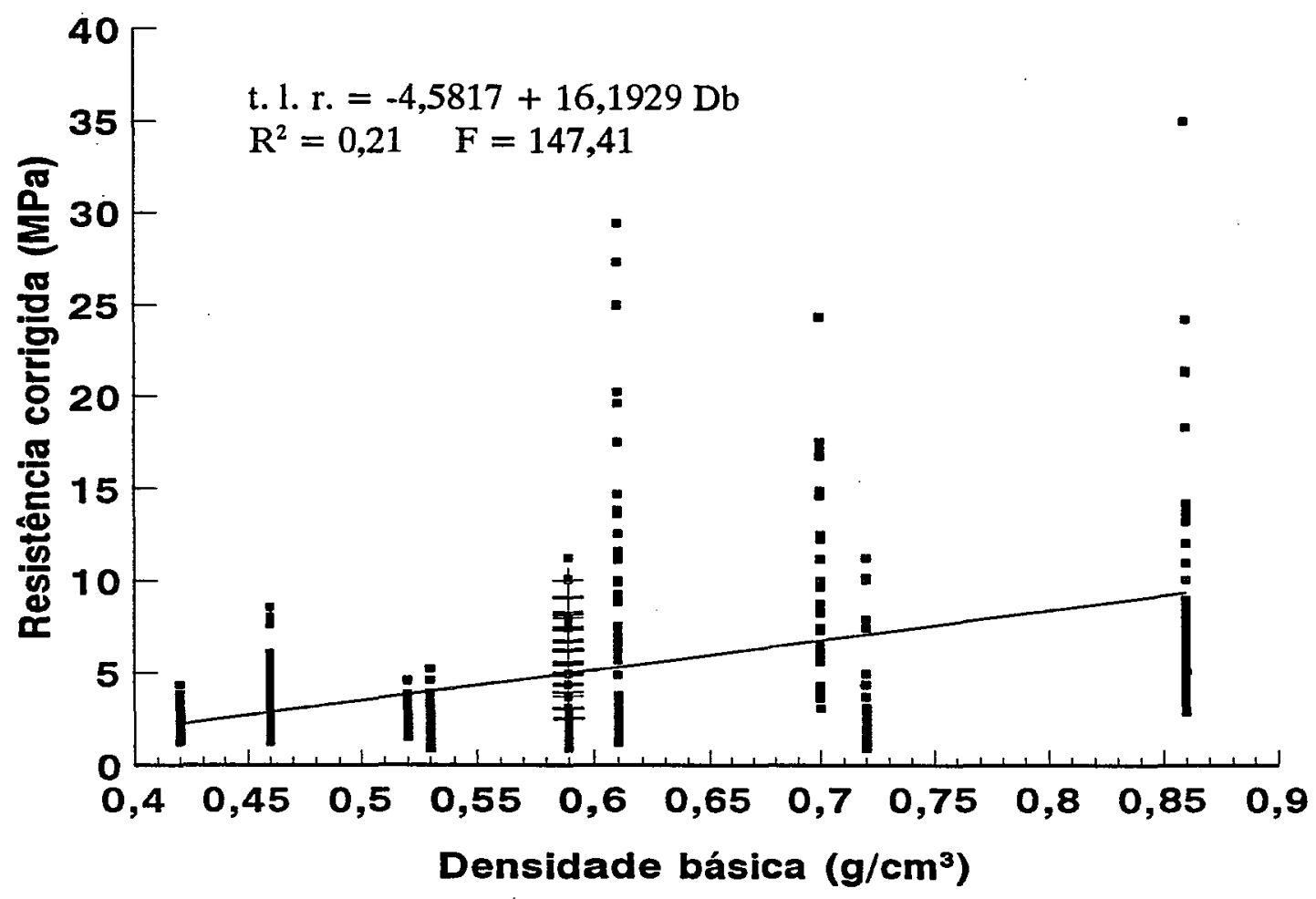

Figura 11. Representação gráfica da correlação entre a resistência corrigida e a densidade básica.

Disto se deduz que a qualidade da lâmina depende mais dos parẩmetros utilizados no beneficiamento da madeira, do que considerar-se a densidade básica como padrão de qualidade. Assim, variáveis controláveis de beneficiamento tem que serem ajustadas para cada espécie individualmente.

Da mesma forma, o ensaio de resistência a tração normal aparenta não ser o mais adequado para avaliar a qualidade das lâminas obtidas por desenrolamento, principalmente quando são comparadas diferentes espécies submetidas ao mesmo padrão de corte.

Comparando o comportamento das espécies durante a laminação e a secagem com os demais parâmetros de avaliação de qualidade, observa-se que 
as lâminas de Guariúba e Piquiarana são as menos recomendáveis tecnicamente. Já as espécies Piquiá-marfim e Faveira folha-fina apesar de apresentarem defeitos, podem ser usadas, desde de que pequenos ajustes sejam feitos nos programas de aquecimento e regulagens no torno.

Sob as condições padrões de corte, as espécies Cedrorana, Breu vermelho, Cardeiro, Louro gamela e Ucuúba branca, foram as que apresentaram as lâminas de melhor qualidade podendo ser utilizadas de pronto sob estes parâmetros estudados.

Uma análise geral dos defeitos observados nas lâminas e as possíveis medidas corretivas é apresentada na Tabela 15.

Tabela 15. Defeitos: possíveis causas e medidas corretivas.

\begin{tabular}{|c|c|c|c|}
\hline Espécies & Defeitos & Possivieis Causas & $\begin{array}{l}\text { Possíveis Medidas } \\
\text { Corretivas }\end{array}$ \\
\hline Ucuúba-branca & $\begin{array}{l}\text { - Baixa tensão normal } \\
(0,92 \mathrm{MPa}) \\
- \text { Fendas profundas de } \\
\text { laminação }(62 \%)\end{array}$ & $\begin{array}{l}\text { - Baixa pressão na } \\
\text { barra }\end{array}$ & $\begin{array}{l}\text { - Aumentar um pouco a } \\
\text { pressão na barra }\end{array}$ \\
\hline Cedrorana & $\begin{array}{l}\text { - Fendas profundas de } \\
\text { laminação }(70 \%)\end{array}$ & $\begin{array}{l}\text { - Baixa pressão na } \\
\text { barra } \\
\text { - Inadequado programa } \\
\text { de aquecimento }\end{array}$ & $\begin{array}{l}\text { - Aumentar um pouco a } \\
\text { pressão na barra } \\
\text { - Aumentar o tempo de } \\
\text { aquecimento }\end{array}$ \\
\hline Louro gamela & $\begin{array}{l}\text { - Baixa tensão normal } \\
(0,73 \mathrm{MPa}) \\
\text { - Rugosidadade acentuada } \\
\text { - Fendas profundas de } \\
\text { laminação }(67 \%)\end{array}$ & $\begin{array}{l}\text { - Baixa pressão na } \\
\text { barra } \\
\text { - Falta de aquecimento }\end{array}$ & $\begin{array}{l}\text { - Aumentar um pouco a } \\
\text { pressão na barra } \\
\text { - Aquecer adequadamente } \\
\text { as madeiras }\end{array}$ \\
\hline Cardeiro & $\begin{array}{l}\text { - Canais secretores } \\
\text { - Baixa tensão normal } \\
(0,86 \mathrm{MPa})\end{array}$ & $\begin{array}{l}\text { - Estrutura vegetativa } \\
\text { - Baixa pressão na } \\
\text { barra }\end{array}$ & $\begin{array}{l}\text { - Anelar a árvore a pelo } \\
\text { menos } 8 \text { meses antes da } \\
\text { derrubada } \\
\text { - Aumentar um pouco a } \\
\text { pressão na barra e tempo e } \\
\text { temperatura de aqueci- } \\
\text { mento }\end{array}$ \\
\hline
\end{tabular}


Tabela 15. Defeitos: possíveis causas e medidas corretivas (continuação).

\begin{tabular}{|c|c|c|c|}
\hline Guariúba & $\begin{array}{l}\text { - Ondulações superficiais } \\
\text { - Rugosidade acentuada } \\
\text { - Fendas profundas de } \\
\text { laminação }(80 \%)\end{array}$ & $\begin{array}{l}\text { - Má regulagem do } \\
\text { torno e/ou inadequado } \\
\text { programa de secagem } \\
\text { - Aquecimento inade- } \\
\text { quado e falta de } \\
\text { pressão na barra }\end{array}$ & $\begin{array}{l}\text { - Regular o torno de } \\
\text { maneira a mais correta } \\
\text { possível } \\
\text { - Fazer um programa de } \\
\text { secagem mais brando em } \\
\text { tempo e temperatura } \\
\text { - Aumentar o tempo de } \\
\text { aquecimento e pressão na } \\
\text { barra }\end{array}$ \\
\hline Piquiarana & $\begin{array}{l}\text { Desgaste da faca } \\
\text { (abrasão e quebra) } \\
\text { - Vibrações no conjunto } \\
\text { cortante } \\
\text { - Ondulações superficiais } \\
\text { - Rugosidade acentuada } \\
\text { - Espessura superior a } \\
\text { nominal } \\
\text { - Fendas profundas de } \\
\text { laminação (83\%) }\end{array}$ & $\begin{array}{l}\text { - Presença de nós e/ou } \\
\text { sílica } \\
\text { - Ângulo da faca muito } \\
\text { grande } \\
\text { - Má regulagem do } \\
\text { torno e/ou inadequado } \\
\text { programa de secagem } \\
\text { - Aquecimento inade- } \\
\text { quado e falta de } \\
\text { pressão na barra }\end{array}$ & $\begin{array}{l}\text { - Aumentar o tempo de } \\
\text { aquecimento e/ou utilizar a } \\
\text { faca com aço especial } \\
\text { - Regular o torno de } \\
\text { maneira mais correta } \\
\text { possivel (diminuir o ângulo } \\
\text { da faca e aumentar um } \\
\text { pouco a pressão na barra) } \\
\text { - Fazer um programa de } \\
\text { secagem mais brando em } \\
\text { tempo e temperatura }\end{array}$ \\
\hline Cupiúba & $\begin{array}{l}\text { - Rugosidade excessiva } \\
\text { - Espessura superior a } \\
\text { nominal } \\
- \text { Baixa tensão normal } \\
(0,74 \mathrm{MPa}) \\
\text { - Fendas profundas de } \\
\text { laminação }(90 \%)\end{array}$ & $\begin{array}{l}\text { - Aquecimento inade- } \\
\text { quado } \\
\text { - Baixa pressão na } \\
\text { barra }\end{array}$ & $\begin{array}{l}- \text { Aumentar tempo e } \\
\text { temperatura de aqueci- } \\
\text { mento } \\
\text { - Aumentar um pouco a } \\
\text { pressão na barra }\end{array}$ \\
\hline $\begin{array}{l}\text { Faveira follha- } \\
\text { fina }\end{array}$ & $\begin{array}{l}\text { - Desgaste da faca } \\
\text { (abrasão e quebra) } \\
\text { - Vibrações do conjunto } \\
\text { cortante } \\
\text { - Ondulações superficiais } \\
\text { - Rugosidade excessiva } \\
\text { - Espessura superior a } \\
\text { nominal }\end{array}$ & $\begin{array}{l}\text { - Presença de nós e/ou } \\
\text { sílica } \\
\text { - Ângulo da faca muito } \\
\text { grande } \\
\text { - Má regulagem do } \\
\text { torno e/ou inadequado } \\
\text { programa de secagem } \\
\text { - Aquecimento inade- } \\
\text { quado e falta de pres- } \\
\text { são na barra }\end{array}$ & $\begin{array}{l}\text { - Aumentar tempo e tempe- } \\
\text { ratura de aquecimento e/ou } \\
\text { utilizar faca com aço } \\
\text { especial } \\
\text { - Regular o torno de } \\
\text { maneira mais correta } \\
\text { possivel (diminuir o ângulo } \\
\text { da faca e aumentar um } \\
\text { pouco a pressão na barra) } \\
\text { - Fazer um programa de } \\
\text { secagem mais brando em } \\
\text { tempo e temperatura }\end{array}$ \\
\hline
\end{tabular}


Tabela 15. Defeitos: possíveis causas e medidas corretivas (continuação).

\begin{tabular}{|c|c|c|c|}
\hline Piquiá-marfim & $\begin{array}{l}\text { Desgaste da faca } \\
\text { (abrasão e quebra) } \\
\text { - Vibrações no conjunto } \\
\text { cortante } \\
\text { - Fibras superficiais soltas } \\
\text { - Aumento na largura nas } \\
\text { fendas de topo } \\
\text { - Rugosidade excessiva } \\
\text { - Espessura superior a } \\
\text { nominal } \\
\text { - Fendas profundas de } \\
\text { laminacão }(80 \%)\end{array}$ & $\begin{array}{l}\text { - Presença de nós e/ou } \\
\text { silica } \\
\text { - Ângulo da faca muito } \\
\text { grande } \\
\text { - Ângulo do contra- } \\
\text { faca muito agúdo } \\
\text { - Aquecimento inade- } \\
\text { quado e falta de pres- } \\
\text { são na barra }\end{array}$ & $\begin{array}{l}\text { - Aumentar tempo e } \\
\text { temperatura de aqueci- } \\
\text { mento e/ou utilizar faca } \\
\text { com aço especial } \\
\text { - Regular o torno da } \\
\text { maneira mais correta o } \\
\text { possivel (diminuir o ângulo } \\
\text { da faca, aumentar um } \\
\text { pouco a pressão na barra } \\
\text { abaloar um pouco o fio do } \\
\text { contra-faca }\end{array}$ \\
\hline
\end{tabular}

\subsection{Avaliação dos compensado.}

Os resultados dos testes de qualificação do compensado (resistência ao cizalhamento e porcentagem de falha na madeira), estão reunidos na Tabela 16.

$\mathrm{Na}$ Tabela 17, são apresentadas as especificações mínimas dos requisitos (resistência ao cisalhamento e falha na madeira) exigidos pela norma NBS/PS 51-71 para compensados a prova d'agua.

Analisando a Tabela 16 e a Figura 12, observa-se que a resistência do compensado esta relacionada com a densidade básica da madeira, fato que pode ser explicado pelo efeito agregador do adesivo exercido sobre as lâminas, eliminando em parte a influência das fendas de laminação. 
Tabela 16.. Valores de resistência ao cisalhamento e falha na madeira das espécies estudadas, nas condições seca e úmida (entre parênteses são apresentados os valores do desvio padrão).

\begin{tabular}{|l|c|c|c|c|c|c|}
\hline \multirow{3}{*}{ Espécie } & \multicolumn{2}{|c|}{$\begin{array}{c}\text { Tensão média de } \\
\text { cisalhamento } \\
\end{array}$} & \multicolumn{2}{|c|}{$(\mathrm{MPa})$} & \multicolumn{4}{c|}{ Mínimo de falha na madeira (\%) } \\
\cline { 2 - 7 } & seca & úmida & 年ostra & \multicolumn{2}{c|}{ Média da peça testada } \\
& individual & & \\
\hline Ucuúba branca & $2,03(0,43)$ & $0,96(0,28)$ & 10,50 & 10,00 & $54,31(26,06)$ & $28,43(16,83)$ \\
\hline Cedrorana & $2,48(0,61)$ & $1,58(0,42)$ & 11,79 & 10,08 & $56,00(27,86)$ & $37,82(23,02)$ \\
\hline Louro gamela & $1,84(0,36)$ & $1,15(0,34)$ & 1,76 & 1,02 & $42,60(24,71)$ & $22,69(17,70)$ \\
\hline Breu vermelho & $1,96(0,57)$ & $1,11(0,40)$ & 13,84 & 5,87 & $60,64(22,83)$ & $33,68(23,62)$ \\
\hline Cardeiro & $2,62(0,57)$ & $1,41(0,42)$ & 14,74 & 4,72 & $51,90(20,27)$ & $36,04(20,30)$ \\
\hline Guariúba & $2,24(0,44)$ & $1,63(0,30)$ & 25,87 & 10,27 & $81,01(18,77)$ & $56,40(30,20)$ \\
\hline Piquiarana & $2,29(0,60)$ & $2,00(0,45)$ & 10,00 & 10,14 & $74,44(18,64)$ & $58,98(22,06)$ \\
\hline Cupiúba & $3,01(0,34)$ & $2,01(0,49)$ & 20,76 & 12,79 & $67,82(20,86)$ & $50,09(25,44)$ \\
\hline Faveira folha-fina & $3,13(0,45)$ & $2,22(0,42)$ & 10,58 & 10,06 & $43,17(24,78)$ & $38,00(25,14)$ \\
\hline Piquiá-marfim & $3,24(0,48)$ & $1,80(0,35)$ & 11,04 & 11,25 & $65,35(26,04)$ & $46,39(31,23)$ \\
\hline
\end{tabular}

Obs.: O resultado é calculado pela média dos três painéis (54 corpos de prova) por espécie, tanto na condição seca quanto úmida. O resultado da amostra individual é o menor valor encontrado por corpo de prova para cada espécie.

Tabela 17. Mínimo aceitável de falha na madeira em função da resistência ao cisalhamento, para linhas de cola à prova d'água (Norma NBS/PS 5171).

\begin{tabular}{|c|c|c|}
\hline \multirow{2}{*}{$\begin{array}{c}\text { Tensão Média de } \\
\text { Cisalhamento }\end{array}$} & \multicolumn{2}{|c|}{ Mínimo de Falha na Madeira (\%) } \\
\cline { 2 - 3 }$(\mathrm{MPa})$ & Amostra Individual & Média da Peça Testada \\
\hline Até 1,8 & 25 & 50 \\
De 1,8 a 2,5 & 10 & 30 \\
Acima de 2,5 & 10 & 15 \\
\hline
\end{tabular}




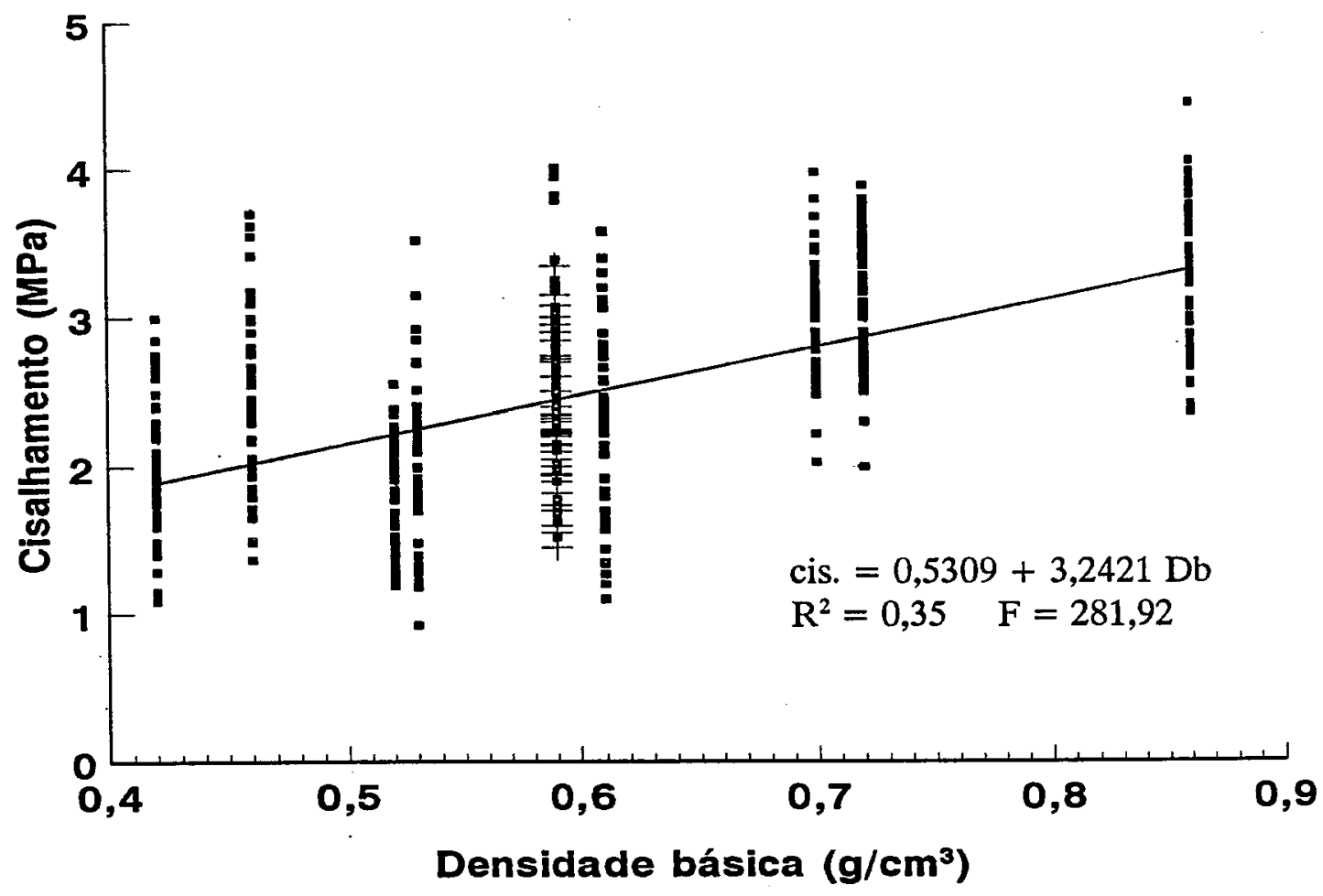

Figura 12. Representação gráfica da correlação entre a tensão de ruptura ao cisalhamento, na condição seca, e a densidade básica.

No confronto das especificações da norma com os resultados obtidos, apenas as espécies Piquiá-marfim, Piquiarana, Cupiúba, Faveira folhafina, alcançaram os valores exigidos para compensados a prova d'água para caso deste trabalho.

As prováveis causas da não qualificação dos compensados, bem como as medidas corretivas mais indicadas, constam da Tabela 18. 
Tabela 18. Desqualificação: possível causas e medidas corretivas.

\begin{tabular}{|c|c|c|}
\hline Espécie & $\begin{array}{c}\text { Possíveis causas da } \\
\text { desqualificação }\end{array}$ & Possíveis medidas corretivas \\
\hline $\begin{array}{l}\text { Ucuúba branca } \\
\text { Cedrorana } \\
\text { Breu vermelho } \\
\text { Cardeiro } \\
\text { Guariúba }\end{array}$ & $\begin{array}{l}\text { - Superficie inativa (secagem } \\
\text { excessiva e/ou } \\
\text { endurecimento superficial) } \\
\text { - Alta viscosidade (pré-cura) }\end{array}$ & $\begin{array}{l}\text { - Fazer um programa de } \\
\text { secagem mais brando em tempo } \\
\text { e temperatura } \\
\text { - Controlar melhor a viscosi- } \\
\text { dade ou usar um adesivo menos } \\
\text { viscoso }\end{array}$ \\
\hline Louro & $\begin{array}{l}\text { - Superficie inativa (secagem } \\
\text { excessiva e/ou } \\
\text { endurecimento superficial) } \\
\text { - Extrativos }\end{array}$ & $\begin{array}{l}\text { - Fazer um programa de } \\
\text { secagem mais brando em tempo } \\
\text { e temperatura } \\
\text { - Aquecer apropriadamente a } \\
\text { madeira }\end{array}$ \\
\hline
\end{tabular}

\subsection{Recomendações de uso.}

Seguindo a linha diretriz deste trabalho, mesmo a despeito da incompatibilidade dos resultados de avaliação das lâminas em relação ao compensado, recomenda-se as espécies Piquiá-marfim, Cupiúba, Faveira folhafina e Cedrorana, para uso como laminado para compensado a prova d'água.

Os problemas apresentados por estas espécies, como desgaste da faca (ruptura, deformação e abrasão), vibrações no conjunto cortante e outros defeitos de laminação, podem ser evitados tomando-se as seguintes providências:

1) Antes das toras serem laminadas, há necessidade que seja feita uma seleção das mesmas quanto a sanidade e defeitos naturais, como nós, tecidos de cicatrização e incrustações de substâncias estranha a madeira, isto elimina problemas de ruptura e deformações do fio da faca.

2) Já a abrasividade é um problema mais difícil de se resolver. Todavia, como esta pode variar muito entre árvores de uma mesma espécie, é possível efetuar uma 
seleção em função desta variação através de aparelhos baseados em princípios similares aos da serra dinamométrica, esta seleção permite eliminar árvores mais abrasivas. Uma outra solução, é utilizar facas feitas de aço especial mais resistente a abrasão.

Outros defeitos apresentados por estas espécies, como vibrações conjunto cortante, e lâminas de qualidade inferior, podem ser melhorados com pequenos ajustes no ângulo da faca, ângulo de afiação da faca, aberturas horizontal e vertical, combinados com um adequado programa de aquecimento.

\subsection{Recomendações de pesquisas.}

As recomendações aqui sugeridas, são baseadas nas observações feitas durante a passagem das espécies nas diferentes etapas de fabricação do compensado, e na relação entre a matéria-prima, o processo e o produto.

Desta forma, recomenda-se a realização de estudos que visem amenizar ou eliminar as fortes ondulações superficiais apresentadas nas lâminas das espécies Guariúba e Piquiarana, durante a secagem. Sugere-se como ponto de partida os seguintes procedimentos:

a) Modificações no programa de aquecimento;

b) Modificações nas regulagens do torno;

c) Modificações no programa de secagem.

Devido a baixa falha na madeira e a grande quantidade de extrativos existentes nas espécies Breu vermelho, Cardeiro e Louro gamela, recomenda-se a realização de estudos que visem identificar a influência destes extrativos sobre a madeira durante a colagem. Sugere-se como ponto de partida as seguintes providências: 

d) Qualificar os extrativos;
e) Aquecer apropriadamente a madeira;
f) Modificar a formulação do adesivo;
g) Modificar as condições de colagem como tempo, temperatura e pressão. 


\section{CONCLUSÕES.}

Com base nas análises dos resultados obtidos, e considerando-se as limitações do presente estudo, pode se concluir que:

- Um mesmo tratamento, nas diversas etapas de fabricação do laminado e do compensado, não deve ser utilizado quando se trabalhar com diferentes espécies madeireiras, haja visto a heterogeneidade dos resultados de qualidade;

- As condições de aquecimento e de regulagem do torno não se mostraram ideais para a laminação das espécies Piquiá-marfim, Piquiarana e Faveira folha-fina por ocasionarem vibrações no conjunto cortante, com prejuízo a qualidade das lâminas em rugosidade e profundidade das fendas de laminação;

- As condições de secagem imposta ocasionaram ondulações na superfície e laterais nas lâminas das espécies Piquiarana, Guariúba e Faveira folha-fina;

- A espessura das lâminas apresentou uma correlação direta com a densidade básica (madeiras densas resultam em lâminas mais espêssas), demonstrando que espécies densa sofrem menor deformação em resposta a compressão da barra durante o corte;

- Como era esperado, madeiras mais densas resultam em lâminas e paíneis com maior resistência mecânica;

- A densidade básica, como parâmetro de qualidade, não é o fator mais importante para se estimar as características do paínel, provavelmente, as condições de corte e secagem das lâminas, bem como a colagem do paínel, são fatores mais 
importantes para definir as características do produto final;

- Todas as espécies estudadas podem ser utilizadas na produção de compensados, sendo que a qualidade das lâminas irá definir seu uso como capa ou miolo, e as características de colagem definirão a classificação para uso interno ou externo. 


\section{REFERÊNCIAS BIBLIOGRÁFICAS.}

AMERICAN SOCIETY FOR TESTING AND MATERIALS. Designation: D85 72 . Veneer, Plywood, and other Glued Veneer Constructions. Philadelphia, ASTM, Vol. 22. 1976.

BLOOMQUIST, P.R. Southern pine playwood adhesives technology. Forest Indusries, 1966. p.39-41.

CHOW, S. Lathe-check influence on plywood shear strength. Can. For. Serv. Inf. Rep. VP-X-122, 1973.

CHUNG, C.H.C. Influencia de la compresion de la barra, angulo de la, y temperatura de coccion de las rolas en la calidad de la chapa de la espécie Terminalia amazonia (Gmel.) Exell., producida por corte rotatorio. Merida, 1979. 47p.( Mestrado-Universidad de los Andes ).

COMISION PANAMERICANA DE NORMAS TÉCNICAS. Maderas: Método de determinacion del peso específico aparente. COPANT, $\mathrm{N}^{\circ} 30: 1-004$, Jun. 1971.

COMSTOCK, G.L. The kinetics of veneer jet drying. Forest Products Journal. 21 (9): 104-11lp. 1971.

DELGADO, G. A. Produccion y secado de chapas de 23 maderas de los altos llanos occidentales de Venezuela. Laboratorio Nacional de Productos Forestales. Merida, Venezuela. 50p. 1976. 
FEDATO, L. C., MENDES, I. C. A. \& CORADIN, V. T. R. Madeiras da Amazônia - Descrição do Lenho de 40 Espécies Ocorrentes na Floresta Nacional do Tapajós. Ministério do Interior, Instituto Brasileiro do Meio Ambiente e dos Recursos Naturais Renováveis / Laboratório de Produto Florestais (IBAMA/LPF), Brasília, 155 p, 1989.

FEIHL, O. \& GODIN, V. Setting veneer lathe with aid of instruments, Ottawa, Canadian Forest Service, publication, $1206.1970 .42 p$.

SOBRAL FILHO, M. Adesão e adesivos para madeira. I - Teoria de adesão e a natureza das colagens com madeira. Série técnica $n^{\circ} 5$. MINISTÉRIO DA AGRICULTURA. Brasília, 1982. 22p.

FLENLEY, J. The Equatorial Rainforest a Geological History. Boston, Butterworths. 1979.

FOCKEL, C. MORA, C. \& MONOCHELLI, S. Densidade básica: Sua verdadeira utilidade como índice de qualidade da madeira de Eucalipto para a produção de celulose. In: CONGRESSO FLORESTAL BRASILEIRO, $6^{\circ}$, Campos do Jordão, 1990. Anais. 1990. Vol. 3. p.719-728.

GALVÃO, A.P.M. \& JANKOWSKY, I. P. Influência da umidade nas características da madeira. In: GALVÃO, A.P.M. \& JANKOWSKY, I.P. Secagem racional da madeira: $1^{\text {a }}$ Ed. São Paulo, Nobel, 1988. 111 p.

GROSSER, D. Defeitos da madeira. Série técnica ${ }^{\circ}$ 2. FUPEF. Curitiba. 62p. 1980.

INSTITUTO BRASILEIRO DE DESENVOLVIMENTO FLORESTAL (IBDF). Norma de controle de qualidade e classificação de compensados. Brasília, Departamento de industrialização e comercialização. 79p. 1985.

INSTITUTO NACIONAL DE PESQUISAS DA AMAZÔNIA (INPA). Inventário Florestal da UHE de Balbina. Manaus, Departamento de Silvicultura Tropical, 111p. 1983. 
KIVIMAA, E. Investigating rotary veneer cutting with of a tension test. Forest Products Journal. 6 (7): 251-255. 1956.

$\mathrm{KOCH}, \mathrm{P}$. Utilization of southern pines. Washington, USDA. Forest service, Southern pines forest experiment station, Agriculture handbook, $\mathrm{n}^{\circ} 420$, vol. 2. 1972.

KOLLMANN, F.F.P. \& COTE, W.A. Principles of wood science and technology. Tomo 2. New York. Spring Verlag. 1968.

, KUENZI,E. \& STAM, A. J. Principles of wood science and technology - Wood based materials. Berlin springer, Verlag. vol. 2, 703p. 1975.

KRAMER, P. J. \& KOZLOWSKI, T. Crescimento e estrutura. In: KRAMER, P. J. \& KOZLOWSKI, T. Fisiologia das árvores. Lisboa, Calouste Gulbenkian, 742p. 1972.

LIMBACH, J. P. A method of measuring checks in veneer. Journal of Forest (Amer.). 44 (2): 509-511. 1946.

LONDOÑO, A. A. Adaptabilidade del chupon (Pouteria aff. P. anibifolia) para la produccion de chapa por corte rotatorio. Merida, 1970. 56p. (Mestrado Universidad de los Andes). 
LOUREIRO, A. A., SILVA, M. F. \& ALENCAR, J. C. Essências madeireiras da Amazônia, Manaus, vol. 2. INPA. 1979.

LUTZ, J. F. Heating veneer bolts to improve quality of douglas-fir plywood. Forest Products Laboratory, $\mathrm{n}^{\circ}$ 2182. 1960. 14p.

\& PATZER, R. A. Effects of horizontal roller bar opening on quality of rotary - Cut southern pine and yellow poplar veneer. Forest Products Journal. 16 (10): 15-25. 1966.

Research at forest products laboratory reveals that heating. Southern pine bolts improves veneer quality. Plywood \& panel: 21-28, 1967.

-------. Techniques for peeling, slicing, and drying veneer. USDA. Forest service FPL research paper, Madison (228): 1-64. 1974.

-------.. Wood veneer: Log selection cutting and drying. USDA. Forest service. Technical bulletin $n^{\circ} 1577$. Visconsin, 1978; 137p.

MAINIERI, A. A. C. \& CHIMELO, J. P. Fichas de Características das Madeiras Brasileiras, Instituto de Pesquisa Tecnológicas do Estado de São Paulo, $2^{a}$ ed., São Paulo, Publicação IPT, nº 1791, 1989. 
MEDINA, J. C. Efeito da temperatura de aquecimento na obtenção de lâminas por desenrolamento e sobre a qualidade da colagem de compensados fenólicos de Pinus elliottii Engelm. Curitiba, 1986. 113p. (Mestrado - Universidade Federal do Paraná).

NATIONAL BUREAU OF STANDARDS. Voluntary Product Standard PS 5171. Hardwood and Decorative Plywood 18p. 1972.

ORGANIZACION DE LAS NACIONES UNIDAS PARA LA AGRICULTURA Y LA ALIMENTACION. Tableros contrachapados y otros paneles a base de madera. Roma, FAO, 1968. 250p.

PRANCE, G. T., RODRIGUES, W. A. Inventário florestal de um hectare de mata de terra-firme Km. 30 da estrada Manaus Itacoatiara. In: PRANCE, G.T., RODRIGUES,W.A. \& SILVA, M.F. Acta amazônica, Manaus, INPA, 1976. $6(1): 9-35$.

BURGER, L. M. \& RICHTER, H. G. Anatomia da madeira. $1^{\text {a }}$ ed. São Paulo, Nobel, 1991. 154p.

RIVERA, A. Maderas de Guayana Produccion y Secado de Chapas. Laboratório Nacional de Productos Forestales. Merida, Venezuela. 27p. 1969.

SEBRAE: SERVIÇO BRASILEIRO DE APOIO ÀS MICROS E PEQUENAS EMPRESAS. Diagnóstico do subsetor madeireiro do estado do Amazonas. Manaus, 76p. 1994. 
SILVA, F. M. Madeiras do Amazoans para a Produção de Laminados e Compensados. In: ENCONTRO BRASILEIRO EM MADEIRAS E ESTRUTURA DE MADEIRA. $3^{\circ}$. São Carlos, 1989. Anais 4 (65): 65-102. 1989.

SOUZA, F. C. Formas para lajes de concreto armado - Madeira compensada. Porto Alegre, 1962. 127p. (Mestrado - Universidade do Rio Grande do Sul).

TOMASELLI, I. The influence of high-temperature drying on some physical and mechanical properties of Pinus radiata D. Don. Melbourne, University of Melbourne, Faculty of Agriculture and Forestry, 1977. 264p. (Tese de doutorado).

Secagem das lâminas para indústrias de painéis. Madeira/Móveis, 1 (1): 27-33. 1983.

------.-. Introdução de espécies pouco conhecidas na indústria de compensados na Amazônia. In:CONGRESSO INTERNACIONAL DE COMPENSADOS DE MADEIRAS TROPICAIS, $1^{\circ}$. Manaus, 1992. ANAIS, 73-94. 1992.

US DEPARTMENT OF AGRICULTURE. The manufacture of veneer. Forest Ptoducts Laboratory, $\mathrm{n}^{\circ} 285.9$ p. 1962.

VETTER, R. E. \& SILVA, F. M. Metodologia para avaliação da colagem em painéis compensados. Acta amazonica, 18 (3-4): 269-273. 1988. 